\title{
De betekenis van de Algemene wet bestuursrecht voor Curaçao
}

\author{
Prof. mr. L.J.J. Rogier ${ }^{*}$
}

\section{Inleiding}

Juristen in Curaçao - vooral zij die (deels) in Nederland zijn opgeleid - vragen zich soms af wat de betekenis is van de Nederlandse Algemene wet bestuursrecht (Awb) voor de rechtspraktijk in Curaçao. De Awb is een Nederlandse wet die niet van kracht is in Curaçao, maar waarop in Curaçao wel vaak een beroep wordt gedaan. Met de Awb wordt dan nader betekenis gegeven aan bestuursrechtelijke regels die in Curaçao niet zijn opgeschreven of veel minder zijn uitgewerkt. En dan rijzen er vragen. Kan dat altijd? En als dat kan, aan welke grenzen is het overnemen of analoog toepassen van regels uit de Awb in Curaçao dan gebonden?

Hierna wordt getracht op deze vragen antwoord te geven. Deze bijdrage is beperkt tot de betekenis van de Awb voor het bestuursrecht van Curaçao. De als bijlagen opgenomen vergelijkingstabellen Awb - Lar en Lar - Awb kunnen daarbij behulpzaam zijn. Voor Aruba, Sint Maarten en de BES-eilanden kunnen vergelijkbare vragen gesteld worden, maar daarvan is afgezien, omdat het bestuurs(proces)recht van de Caribische delen van het Koninkrijk (helaas) steeds meer uiteen begint te lopen. ${ }^{1}$

Allereerst wordt gewezen op enkele uitgangspunten voor analoge toepassing in het algemeen en van (bestuurs)wetgeving in de landen van het Koninkrijk en de Awb in het bijzonder. Vervolgens wordt ingegaan op analoge en niet-analoge toepassing van de Awb. Daarbij wordt onderscheid gemaakt tussen bevoegdheden en verplichtingen van bestuursorganen, bevoegdheden en verplichtingen van rechters, en rechten, verplichtingen en aanspraken van burgers. Onder 'bevoegdheid' wordt hier verstaan het aan het publiekrecht ontleende recht om rechtshandelingen te verrichten. Bevoegdheden zijn voorbehouden aan overheidsorganen. Van een 'recht' wordt gesproken als het iemand is toegestaan een bepaalde handeling te verrichten of na te laten die een ander zich in het algemeen niet kan veroorloven. Rechten van overheidsorganen worden meestal ook bevoegdheden genoemd. Een 'verplichting' is een rechtens geboden handeling. En onder 'aanspraak' wordt hier verstaan het subjectieve recht tot een bepaald object of tot handelen of nalaten van een ander. ${ }^{2}$ De jurisprudentie die wordt aangehaald verwijst behalve naar Curaçaose

* Prof. mr. L.J.J. Rogier is hoogleraar staats- en bestuursrecht aan de University of Curaçao. Hij is tevens redactielid van het Caribisch Juristenblad.

1 Ondanks de 'Samenwerkingsregeling eenvormig procesrecht', Curaçaosche Courant 27 augustus 2010.

2 Vgl. W. Duk, Recht en slecht. Beginselen van een algemene rechtsleer, Nijmegen: Ars Aequi Libri 1999, p. 157, 163 en 177 . 
voorbeelden ook naar voorbeelden uit de tijd van de Nederlandse Antillen, vóór 10 oktober 2010, toen Curaçao nog geen autonoom land was binnen het Koninkrijk, en naar voorbeelden uit Sint Maarten, omdat de Lar in dat land vrijwel identiek is aan de Lar van Curaçao.

\section{Uitgangspunten voor analoge toepassing}

Volgens Duk kan een regel alleen dan analoog worden toegepast als ten minste aan drie voorwaarden is voldaan: (1) er is geen rechtstreeks toe te passen geldende regel die tot een redelijke beslissing kan leiden; (2) de analoog toe te passen regel handelt over situaties, vergelijkbaar met die van de casus waarin moet worden beslist, en (3) zij behoort tot het rechtsstelsel dat op die casus van toepassing is. ${ }^{3}$

Wat de laatste voorwaarde betreft moet worden vastgesteld dat alle landen van het Koninkrijk hun eigen bestuursrechtelijke wetgeving hebben. Het bestuursrecht valt niet onder het concordantiebeginsel van artikel 39 Statuut voor het Koninkrijk der Nederlanden, dat zegt dat het burgerlijk recht en het strafrecht zo veel mogelijk op overeenkomstige wijze dient te worden geregeld. Maar het Curaçaose bestuursrecht heeft wel veel ontleend aan en gemeen met het Nederlandse bestuursrecht. Reeds bij de opzet van de voorganger van de Landsverordening administratieve rechtspraak (Lar) van Curaçao, de Lar van de toenmalige Nederlandse Antillen, was uitgangspunt daarin zo veel mogelijk gebruik te maken van in de Nederlandse bestuursrechtspraak gehanteerde begrippen, waardoor te rade gegaan kon worden bij de Nederlandse literatuur en rechtspraak. ${ }^{4}$ De begrippen, de doctrine, de leerstukken van en ook de jurisprudentie over het bestuursrecht van Nederland en Curaçao vertonen grote verwantschap. Het ligt dan ook voor de hand om daar waar de regelgeving (vrijwel) gelijkluidend is, de Curaçaose regelgeving analoog aan de Nederlandse regelgeving toe te passen. In de rechtspraak komt dat duidelijk tot uitdrukking. ${ }^{5}$

Daarnaast werkt een aantal in de Awb opgenomen regels, die in Curaçao niet of slechts ten dele zijn opgeschreven, als ongeschreven recht door in het Curaçaose bestuursrecht. ${ }^{6}$ Die analoge toepassing wordt sinds de invoering van de Lar 2001 in de voormalige Nederlandse Antillen mede verzekerd doordat bij hoger beroep in bestuurszaken staatsraden van de Nederlandse Afdeling bestuursrechtspraak van de Raad van State als rechters zitting hebben in het Gemeenschappelijk Hof van Justitie. Maar analoge toepassing heeft zijn grenzen. Een belangrijke beperking voor analoge toepassing vormt het legaliteitsvereiste.

3 Duk 1999, p. 115.

$4 \quad$ MvT Lar, Staten van de Nederlandse Antillen, zitting 1999-2000, nr. 3, p. 4.

5 Zie J.Th. Drop, De invloed van de Nederlandse bestuursrechtspraak op de rechtspraak in Lar-zaken (diss. UoC), Den Haag: Boom Juridische uitgevers 2014 en L.J.J. Rogier, 'Het einde van het concordantiebeginsel?', RMThemis 2016, afl. 3, p. 124-135.

6 Overigens is ook het in de Awb opgeschreven recht niet uitputtend bedoeld. De daarin opgenomen omschrijving van algemene beginselen van behoorlijk bestuur is bijvoorbeeld niet als definitief en volledig bedoeld. En daarnaast zijn er nog vele ongeschreven beginselen.

7 Duk 1999 wijst in dat verband op het verbod van analogie in het strafrecht, zoals blijkt uit de nulla poenaregel van art. 16 Grondwet. Vgl. art. 18 Staatsregeling van Curaçao. 
Zo is voor de toedeling van bevoegdheden aan een bestuursorgaan of aan de rechter, of van rechten, verplichtingen of aanspraken aan burgers een expliciete wettelijke grondslag vereist. In die gevallen kunnen regels uit de Awb in beginsel niet analoog worden toegepast. $^{8}$

Hierna wordt allereerst ingegaan op regels uit de Awb die wel analoog kunnen worden toegepast in Curaçao en op gevallen waarin de wetgeving in Curaçao al dan niet expliciet afwijkt van de Awb. Vervolgens wordt ingegaan op de hiervoor genoemde bevoegdheden en rechten, verplichtingen en aanspraken, waarbij analoge toepassing in beginsel niet mogelijk is en op de uitzonderingen daarop.

\section{Analoge toepassing van de Awb}

Analoge toepassing van regels uit de Awb in Curaçao is mogelijk in gevallen waarin regels identiek of vrijwel identiek zijn. En dat gebeurt ook. Aan (vrijwel) identieke regels wordt hier verder geen aandacht geschonken. ${ }^{9}$ Voor (delen van) regels die niet identiek zijn ligt het voor de hand dat die niet analoog worden toegepast. De Lar-rechter heeft weinig moeite met de interpretatie van het Curaçaose bestuursrecht conform het Nederlandse recht. Nieuwe ontwikkelingen in het Nederlandse bestuurs(proces)recht op basis van de Awb worden in de jurisprudentie met betrekking tot de Lar meegenomen, voor zover althans de bepalingen van de Lar daartoe ruimte laten. ${ }^{10}$ Regelgeving die in Nederland al wel, maar in Curaçao nog niet is gemoderniseerd, wordt veelal toch analoog toegepast. ${ }^{11}$ En verder is het mogelijk dat (delen van ) regels die niet in de Lar, maar wel in de Awb staan als ongeschreven recht in Curaçao gelden. Daarbij gaat het vaak om begripsomschrijvingen en algemene rechtsbeginselen, waaronder beginselen van behoorlijk bestuur en beginselen van behoorlijk procesrecht. Onder de eerste twee hiervoor genoemde voorwaarden van Duk kan de Awb in die gevallen een aanvullende functie vervullen voor het bestuursrecht in Curaçao.

\subsection{Begripsomschrijvingen}

Sommige bepalingen in het Curaçaose bestuursrecht zijn vrijwel letterlijk uit de Nederlandse wetgeving overgenomen en worden door de rechter in Curaçao overeenkomstig de Nederlandse doctrine en jurisprudentie uitgelegd. Dat is duidelijk te zien bij de kernbegrippen van het bestuursrecht, zoals bestuursorgaan, beschikking en belanghebbende. ${ }^{12}$ Deze begrippen in de Lar zijn ontleend aan de Awb of aan de voorganger daarvan, de Wet administra-

8 Vgl. S.E. Zijlstra, 'Naar een landsverordening algemene regels van bestuursrecht?', CJB 2015, afl. 4, p. 270: '(...) als het gaat om verplichtingen van burgers, voorzieningen van rechtsbescherming of ingrijpende bestuursbevoegdheden, brengt het legaliteitsvereiste mee dat de wetgever moet optreden.'

9 Zie daarvoor de vergelijkingstabellen Awb - Lar en Lar-Awb. Zie ook het artikelsgewijs commentaar op de Lar van M.E.B. de Haseth, L.J.J. Rogier \& J. Sybesma, Landsverordening administratieve rechtspraak Curaçao, Den Haag: Boom juridisch 2016, en over de wijzigingen van de Lar in 2015: M.E.B. de Haseth, 'Wijzigingen in de Curaçaose Lar: doelmatiger en doeltreffender rechtsbescherming', CJB 2016, afl. 1, p. 3-20.

10 Rogier 2016, p. 133.

11 Zo wordt in art. 3 lid 2 Lar bij de weigering om een beschikking te geven ook de afwijzing van een aanvraag van een beschikking ingelezen (vgl. art. 1:3 lid 2 Awb) al staat dat daar niet letterlijk. Vgl. Drop 2014, p. 23.

12 Vgl. Zijlstra 2015, p. 272. 
tieve rechtspraak overheidsbeschikkingen (Arob). Zo komt het begrip bestuursorgaan in de Lar overeen met het zogenoemde b-orgaan in de Awb: een persoon of college met enig openbaar gezag bekleed. ${ }^{13}$ In de Lar ontbreekt het a-orgaan: een orgaan van een rechtspersoon die krachtens publiekrecht is ingesteld, omdat de Lar zich uitsluitend richt op rechtsbescherming. A-organen zijn in de Awb opgenomen om ze onder de normerende werking van deze wet te laten vallen. Anders dan de Lar bevat de Awb naast rechtsbeschermingsbepalingen ook bepalingen die het handelen van bestuursorganen normeren, zoals beginselen van behoorlijk bestuur.

Ook het beschikkingsbegrip in de Lar is afgeleid van de Awb. De omschrijving daarvan komt overeen met het beschikkingsbegrip in de Awb: een schriftelijk besluit van een bestuursorgaan inhoudende een publiekrechtelijke rechtshandeling die niet van algemene strekking is. ${ }^{14}$ Maar in de Lar wordt de weigering van een beschikking ${ }^{15}$ en het niet tijdig nemen van een beschikking gelijkgesteld met een beschikking, ${ }^{16}$ terwijl in de Awb de afwijzing van de aanvraag (ook) als een beschikking wordt aangemerkt, terwijl het niet tijdig nemen van een besluit (inclusief beschikking) wordt gelijkgesteld met een besluit. Dat laatste is bedoeld om rechtsbescherming bij de bestuursrechter daartegen mogelijk te maken. ${ }^{17}$

Ten aanzien van het belanghebbendebegrip geldt dat een belanghebbende volgens de Lar in zijn belang moeten zijn getroffen, terwijl de Awb bepaalt dat zijn belangen bij het besluit moeten zijn betrokken. ${ }^{18}$ Ook dat kan worden verklaard doordat de Lar alleen een rechtsbeschermingswet is en de Awb ook op het aan het besluit voorafgaande bestuurlijke besluitvormingstraject betrekking heeft. Verder bepaalt de Awb dat het bij rechtspersonenbelanghebbenden, net zoals in de Lar, moet gaan om belangen die zij krachtens hun doelstellingen en blijkens hun feitelijke werkzaamheden behartigen. De Awb voegt daaraan niet alleen toe dat het moet gaan om algemene en collectieve belangen, maar ook dat het gaat om feitelijke werkzaamheden die zij in het bijzonder behartigen. Uit de wetsgeschiedenis blijkt niet waarom deze elementen uit de Awb niet in de omschrijving van de Lar zijn overgenomen. ${ }^{19}$

Andere overwegend gelijkluidende begrippen betreffen de overige in hoofdstuk 1 van de Awb opgenomen definities en omschrijvingen. Een bestuursrechter is volgens de Awb een onafhankelijk bij wet ingesteld orgaan dat met bestuursrechtspraak is belast. In de Lar wordt met de administratieve rechter alleen het Gerecht in Eerste Aanleg en het Gemeenschappelijk Hof van Justitie bedoeld, voor zover deze colleges beschikkingen beoordelen. Definities van bezwaar, beroep en administratief beroep ${ }^{20}$ ontbreken in de Lar. De bezwaarpro-

13 Art. 2 lid 1 Lar en art. 1:1 aanhef en sub b Awb.

14 Art. 3 lid 1 Lar en art. 1:3 lid 1 jo. 2 Awb.

15 Zie noot 11 .

16 In Curaçao en Sint Maarten wordt, in tegenstelling tot Aruba, het niet tijdig nemen van een beschikking niet inhoudelijk 'ingekleurd' als een weigering. Er blijft een rechtsplicht bestaan om te beslissen. Zie GHvJ 27 november 2006, ECLI:NL:OGHNAA:2006:BG1613; GHvJ 27 november 2006, ECLI:NL:OGHNAA: 2006:BG1617 en GHvJ 20 november 2008, ECLI:NL:OGHNAA:2008:BH1328.

17 Art. 1:3 lid 2 en 6:2 aanhef en sub b Awb.

18 Art. 1 Lar en art. 1:2 lid 1 Awb.

19 Zie Drop 2014, p. 85.

20 Art. 1:5 Awb. 
cedure is onder het kopje bestuurlijke heroverweging inhoudelijk geregeld in hoofdstuk 4 van de Lar. Administratief beroep, beroep bij een ander bestuursorgaan dan hetwelk het besluit heeft genomen, bestaat vrijwel niet meer in Curaçao. ${ }^{21}$ De afbakening tussen het instellen van beroep en een vordering op basis van het civiele recht is in de Awb respectievelijk de Lar in gelijkluidende bewoordingen te vinden onder de uitzonderingen van besluiten respectievelijk beschikkingen waartegen geen beroep kan worden ingesteld: geen beroep staat open tegen een beschikking ter voorbereiding van een privaatrechtelijke rechtshandeling met uitzondering van een beschikking houdende weigering van de goedkeuring van een dergelijk beschikking. ${ }^{22}$ De afbakening met het strafrecht is in de Awb te vinden in hoofdstuk $1^{23}$ en in de Lar bij de uitzonderingen van beschikkingen waartegen geen beroep kan worden ingesteld: geen beroep staat open tegen een beschikking van strafrechtelijke aard. ${ }^{24}$

Het gebruik van gelijke bewoordingen is geen strikt vereiste voor het volgen van de Nederlandse uitleg van een bepaling. ${ }^{25}$ Ook bepalingen die niet in gelijke bewoordingen zijn gesteld, maar die wel dezelfde strekking hebben, worden op gelijke wijze uitgelegd. Te denken valt hierbij aan de niet in de Lar, maar wel in bijzondere Curaçaose landsverordeningen opgenomen omschrijvingen van bestuurlijke sancties, zoals de (last onder) bestuurs$d$ wang, de (last onder) dwangsom en de bestuurlijke boete, ${ }^{26}$ en aan de omschrijving van het subsidiebegrip. ${ }^{27}$ Te denken valt voorts aan begrippen uit de Awb die niet als zodanig zijn te vinden in het geschreven bestuursrecht van Curaçao, zoals mandaat, ${ }^{28}$ delegatie, ${ }^{29}$ attributie en goedkeuring. ${ }^{30}$

Onder mandaat wordt verstaan: de bevoegdheid om in naam van een bestuursorgaan besluiten te nemen. ${ }^{31}$ Voor mandaat is geen wettelijke grondslag nodig. ${ }^{32}$ Dat betekent ook dat submandaat zonder wettelijke grondslag mogelijk is. ${ }^{33}$ Hoewel dat niet als zodanig is geregeld, lijkt het wel waarschijnlijk dat ook in Curaçao in bepaalde gevallen de aard van de bevoegdheid zich tegen mandaatverlening kan verzetten. ${ }^{34}$ Inherent aan mandaat is dat de mandaatgever instructies kan geven aan de gemandateerde voor de uitoefening van de

21 Een van de zeldzame voorbeelden is te vinden in de Landsverordening op de geneesmiddelenvoorziening (PB 1969, nr. 24) die in art. 5 lid 2 administratief beroep openstelt bij de minister van Volksgezondheid en Sociale Ontwikkeling tegen een weigering van de Commissie voor de beoordeling van verpakte geneesmiddelen om een geneesmiddel in te schrijven. Zie over het vervallen van het administratief beroep J.Th. Drop, 'Enkele aspecten van het voorstel tot wijziging van de Lar', CJB 2011, afl. 4, p. 253-256.

23 Art. 1:6 Awb.

24 Art. 7 lid 2 sub i Lar.

25 Drop 2014, p. 335-336.

26 Art. 5:2, 5:21, 5:31d en 5:40 Awb.

27 Vgl. art. 4:21 lid 1 Awb en art. 1 sub a Subsidieverordening Curaçao 2007, AB 2007, nr. 104.

28 Art. 10.1 Awb. Vgl. Zijlstra 2015, p. 273.

29 Art. 10:13 Awb. Vgl. Zijlstra 2015, p. 273.

30 Art. 10:25 Awb.

31 Art. 10:1 Awb.

32 Voor 'ondertekeningsmandaat', art. 10:11 Awb, (dat geen echt mandaat is, want geen beslissing) geldt dat ook.

33 Art. 10:9 Awb.

34 Art. 10:3 lid 1 Awb. 
gemandateerde bevoegdheid. ${ }^{35}$ Uit de begripsomschrijving vloeit verder voort dat een door de gemandateerde binnen de grenzen van zijn bevoegdheid genomen besluit of beschikking geldt als een besluit respectievelijk beschikking van de mandaatgever en dat de mandaatgever bevoegd blijft de gemandateerde bevoegdheid zelf uit te oefenen en het mandaat ook weer in te trekken. ${ }^{36}$

Onder delegatie wordt in de Awb verstaan: het overdragen door een bestuursorgaan van zijn bevoegdheid tot het nemen van besluiten aan een ander die deze onder zijn eigen verantwoordelijkheid uitoefent. ${ }^{37}$ Het bestuursorgaan kan de gedelegeerde bevoegdheid niet meer zelf uitoefenen, maar het delegatiebesluit kan wel te allen tijde worden ingetrokken. Deze regels zijn codificerend van aard. Dat betekent dat ze gebaseerd zijn op ongeschreven recht dat reeds bestond. ${ }^{38}$ Daarom mag worden aangenomen dat ze analoog kunnen worden toegepast en ook tot het ongeschreven recht van Curaçao behoren. Voor delegatie is, anders dan voor mandaat, wel een wettelijke grondslag vereist. ${ }^{39}$ Vanwege het legaliteitsvereiste, dat daaraan ten grondslag ligt, geldt deze regel ook in Curaçao.

In de Lar ontbreekt, evenals in de Awb, een begripsomschijving van attributie. Duidelijk is dat voor attributie (het toekennen van nieuwe bevoegdheden) een wettelijke grondslag nodig is. In de Awb is bepaald dat een bestuursorgaan aan een persoon of college werkzaam onder de verantwoordelijkheid van dit bestuursorgaan, waaraan bevoegdheden zijn geattribueerd ('toebedeeld'), per geval of in het algemeen instructies kan geven ter zake van de uitoefening van die bevoegdheden. ${ }^{40}$ Deze regel is codificerend van aard en kan daarom in Curaçao analoog worden toegepast.

\subsection{Algemene rechtsbeginselen}

Bij de analoge toepassing van regels uit de Awb als ongeschreven recht in Curaçao gaat het, zoals gezegd, vaak om algemene rechtsbeginselen, beginselen van behoorlijk bestuur en beginselen van behoorlijk procesrecht. Algemene rechtsbeginselen hebben betrekking op het gehele recht, algemene beginselen van bestuursrecht alleen op het bestuursrecht en beginselen van behoorlijk procesrecht op het procesrecht, waaronder het bestuursprocesrecht.

Met betrekking tot de functie van algemene beginselen kennen de Awb en de Lar identieke regels. In de Awb is, evenals in de Lar, bepaald dat de rechter in zijn uitspraak dient aan te geven welk algemeen rechtsbeginsel (waaronder het beginsel van behoorlijk bestuur) geschonden is, indien daarvan sprake is. ${ }^{41}$ Ook is in beide wetten bepaald dat een besluit ondanks de schending van een algemeen rechtsbeginsel (waaronder het beginsel van 
behoorlijk bestuur) in stand kan worden gelaten, indien aannemelijk is dat de belanghebbenden daardoor niet worden geschaad. ${ }^{42}$

De Awb noch de Lar benoemen echter specifiek algemene rechtsbeginselen. De Awb geeft in hoofdstuk 2 wel bepalingen voor het verkeer tussen burgers en bestuursorganen. Deze bepalingen kunnen als ongeschreven recht analoog worden toegepast in Curaçao, voor zover ze geen zelfstandige bevoegdheden, rechten, verplichtingen of aanspraken bevatten. Dat is het geval met betrekking tot vrijwel alle artikelen van hoofdstuk 2 Awb, behalve waar het gaat om de geheimhoudingsplicht ${ }^{43}$ en het gebruik van het Nederlands in het bestuurlijk verkeer. ${ }^{44}$ In Curaçao hebben burgers weliswaar niet in algemene zin het recht om zich in het verkeer met bestuursorganen te kunnen laten bijstaan of door een gemachtigde te laten vertegenwoordigen, ${ }^{45}$ maar wel in bezwaar en beroep. ${ }^{46}$ Ook hebben Curaçaose bestuursorganen geen algemene verplichting om geschriften tot behandeling waarvan kennelijk een ander bestuursorgaan bevoegd is door te zenden, maar die verplichting bestaat wel ten aanzien van bezwaar- en beroepschriften. ${ }^{47}$ Een ongeschreven beginsel is voorts dat een bestuursorgaan zijn taak zonder vooringenomenheid dient te vervullen. ${ }^{48}$ Dat vloeit mede voort uit het discriminatieverbod, zoals opgenomen in artikel 3 Staatsregeling van Curaçao. Ten slotte omvat het recht om op grond van de Awb bezwaar en beroep in te stellen mede het recht om dat - onder voorwaarden - elektronisch te doen. ${ }^{49}$ Curaçao kent (nog) geen regelingen met betrekking tot het elektronisch verkeer met het bestuursorgaan en de rechter, maar de Nederlandse regelingen op dat punt worden in Curaçao analoog toegepast. ${ }^{50}$

\subsection{Algemene beginselen van behoorlijk bestuur}

Algemene beginselen van behoorlijk bestuur (abbb) zijn algemene rechtsbeginselen die meer in het bijzonder betrekking hebben op het verkeer tussen burgers en bestuursorganen en op besluiten en beschikkingen. In de $A w b^{51}$ is in de hoofdstukken 3 en 4 een aantal abbb gecodificeerd, zonder dat ze als zodanig zijn aangeduid. Deze Awb-regels kunnen, omdat ze codificerend van aard zijn, in Curaçao analoog worden toegepast, voor zover ze althans geen zelfstandige bevoegdheden, rechten, verplichtingen of aanspraken bevatten en voor zover in het Curaçaose bestuursrecht daarvoor geen specifieke regels zijn te vinden die daarvan afwijken. ${ }^{52}$ Nog voordat de Lar van kracht was, was de invloed van

42 Art. 6:22 Awb en art. 50a Lar.

43 Art. 2:5 Awb. Volgens Zijlstra (2015, p. 272) kan de geheimhoudingsplicht niet aan het ongeschreven recht worden ontleend.

44 Art. 2:6 Awb. In Curaçao geldt de Landsverordening officiële talen (PB 2007, nr. 20) die het Engels, Nederlands en Papiaments aanwijst als officiële talen voor het bestuurlijk verkeer.

45 Art. 2:1 en 2:2 Awb.

46 Art. 15 en 57 Lar. Volgens Zijlstra (2015, p. 272) volgt uit het ongeschreven recht dat men zich in het verkeer met een bestuursorgaan kan laten bijstaan en vertegenwoordigen.

47 Art. 2:3 Awb en art. 9b, 20 en 59 Lar.

48 Art. 2:4 Awb.

49 Art. 2:13-2:17 en 8:40a Awb.

50 Zie GHvJ 6 juni 2017, ECLI:NL:OGHACMB:2017:53. Vgl. M.F. Murray, 'Elektronisch appèl?’, CJB 2014, afl. 1, p. 36-38.

51 In hfdst. 2, 3 en 4, titel 4.1 Awb.

52 Vgl. Zijlstra 2015, p. 273. 
de Awb reeds zichtbaar in de rechtspraak in Curaçao. Zo is in 1997 in een uitspraak van de burgerlijke rechter in Curaçao een omschrijving van het evenredigheidsbeginsel te vinden die vrijwel woordelijk is ontleend aan artikel 3:4 lid 2 Awb. ${ }^{53}$

Hierna wordt onderscheid gemaakt tussen formele en materiële abbb. Formele abbb hebben betrekking op de procedure van totstandkoming, de voorbereiding en de wijze van het nemen van besluiten/beschikkingen. Materiële abbb hebben betrekking op de inhoud van het bestuurlijk handelen.

\subsection{Formele algemene beginselen van behoorlijk bestuur}

Het in hoofdstuk 3 van de Awb opgenomen formele zorgvuldigheidsbeginsel eist dat een publiekrechtelijke of privaatrechtelijke rechtshandeling en ook een feitelijke handeling van de overheid ${ }^{54}$ zorgvuldig wordt voorbereid. Dat wil in de eerste plaats zeggen dat het bestuursorgaan de nodige kennis omtrent de voor de handeling relevante feiten en af te wegen belangen vergaart, de belanghebbenden in de gelegenheid stelt om bij een aanvraag voor een beschikking ontbrekende gegevens aan te vullen en om bij een afwijzing vooraf te worden gehoord. ${ }^{55}$ Voor zover hier sprake is van verplichtingen van bestuursorganen en rechten van burgers hebben die geen zelfstandig karakter, want zij maken deel uit van het (ongeschreven) formele zorgvuldigheidsbeginsel. Daarvoor is derhalve geen afzonderlijke wettelijke grondslag vereist. Het formele zorgvuldigheidsbeginsel houdt bovendien in dat alle bij het besluit betrokken belangen, die bij de voorbereiding in kaart zijn gebracht, in de belangenafweging worden betrokken. ${ }^{56}$ Zo maakten op Curaçao omwonenden bezwaar tegen het verlenen van een bouwvergunning voor een huisje dat hun fraaie uitzicht zou belemmeren. De rechter oordeelde dat aan de verlening van de vergunning ernstige gebreken kleefden. De omwonenden waren niet gehoord en de vergunning was verleend zonder dat was vastgesteld dat discrepanties aanwezig waren tussen de vergunningaanvrage en de verwezenlijking daarvan. Bovendien was het zeer waarschijnlijk dat de vergunning strijdig geacht moest worden met de erfpachtvoorwaarden die voor het desbetreffende perceel en de omliggende percelen golden. Dat alles was niet onderzocht. De vergunning was derhalve onzorgvuldig tot stand gekomen. ${ }^{57}$

Het hiervoor al genoemde, in hoofdstuk 2 van de Awb opgenomen verbod voor het bestuur om te handelen zonder vooringenomenheid ${ }^{58}$ maakt deel uit van het ongeschreven beginsel van fair play, dat nauw verwant is aan het formele zorgvuldigheidsbeginsel. Fair play houdt enerzijds in dat het bestuur burgers in de gelegenheid moet stellen om voor hun belangen op te komen en daartoe genoegzaam inzicht moet geven in de gronden van

Gea Curaçao 15 augustus 1997, TAR-Justicia 1998, afl. 3, p. 179-183, Jurisprudentie Bestuursrecht 1998, p. 76-81 (Godett).

54 Vgl. art. 3:1 Awb en HR 27 maart 1987, AB 1987/273 (Amsterdam Ikon).

55 Zie art. 3:2 Awb en afdelingen 4.1.1 en 4.1.2 Awb. Niet alle regels over het horen zijn overigens van codificerende aard. Zie daarover Zijlstra 2015, p. 273.

56 Vgl. art. 3:4 lid 1 Awb.

57 GHvJ 2 januari 1990, TAR-Justicia, Jurisprudentie Bestuursrecht 1998, p. 212-214 (Seru Mahuma).

58 Art. 2:4 Awb. 
zijn besluitvorming ${ }^{59}$ en anderzijds dat het zich steeds objectief dient op te stellen en onpartijdig dient te handelen. Burgers mogen door het bestuur niet voor de gek worden gehouden of op het verkeerde been worden gezet. Dit beginsel geldt ook in Curaçao.

Het eveneens ongeschreven formele rechtszekerheidsbeginsel eist dat besluiten duidelijk en ondubbelzinnig zijn geformuleerd (duidelijkheidsvereiste). Tot het beginsel behoort ook dat besluiten worden bekendgemaakt (kenbaarheidsvereiste) en niet eerder in werking treden dan nadat ze bekend zijn gemaakt. Daarover bevat de Awb wel regels. Voor zover dat in Curaçao voor beschikkingen niet afzonderlijk is geregeld, ${ }^{60}$ kunnen de in hoofdstuk 3 van de Awb opgenomen regels voor bekendmaking en mededeling ${ }^{61}$ analoog worden toegepast, behalve de verplichting tot het opnemen van een rechtsmiddelenverwijzing. ${ }^{62}$ Daarin voorziet de Lar wel. ${ }^{63}$

Het motiveringsbeginsel heeft betrekking op de wijze waarop het besluit is ingericht. Het bevat twee eisen. Niet alleen moet een besluit een motivering bevatten, maar deze motivering dient bovendien draagkrachtig te zijn en zo mogelijk te verwijzen naar het wettelijk voorschrift waarop ze berust. ${ }^{64}$ In de Lar is het beginsel deels gecodificeerd voor een beslissing op bezwaar. ${ }^{65}$ Maar ook beschikkingen in primo dienen deugdelijk gemotiveerd te zijn. ${ }^{66}$ Daarbij kan de Awb analoog worden toegepast. Dat geldt ook voor het achteraf verstrekken of achterwege laten van een motivering en de verplichting om aan te geven waarom is afgeweken van een krachtens wettelijk voorschrift uitgebracht advies. ${ }^{67}$ Voor de eisen die worden gesteld aan het ter motivering verwijzen naar een uitgebracht advies $^{68}$ lijkt een wettelijke grondslag nodig. Op dit punt kan de Awb derhalve niet analoog worden toegepast. Ten slotte is motivering ook in Curaçao tegenwoordig een vormvereiste waaraan kan worden voorbijgegaan, als blijkt dat belanghebbenden daardoor niet worden benadeeld. ${ }^{69}$

\subsection{Materiële algemene beginselen van behoorlijk bestuur}

Het verbod van détournement de pouvoir houdt in dat een bevoegdheid niet voor een ander doel mag worden aangewend dan waarvoor die bevoegdheid is verleend. ${ }^{70}$ Deze in de Awb opgenomen norm geldt ook in Curaçao als ongeschreven rechtsnorm. Dat bleek reeds in

59 Zie Gea Aruba 30 augustus 1989, TAR-Justicia 1998, Jurisprudentie Bestuursrecht, p. 96-100 (Antilliaanse verloofde), waarin bij een ontzegging van toegang tot Curaçao onvoldoende uitleg werd gegeven over verdenkingen door de politie.

60 Art. 16 lid 2 en 69 lid 2 Lar. Vgl. Zijlstra 2015, p. 272. Zie voor een uitzondering daarop art. 17 lid 4 Landsverordening toelating en uitzetting Curaçao.

61 Art. 3:40 en 3:41 lid 1 Awb.

62 Art. 3:45 Awb.

63 Art. 16 lid 5 Lar.

64 Vgl. art. 3:46 en 3:47 lid 2 Awb.

65 Art. 68 lid 2 Lar. Daar staat niet de verplichting om zo mogelijk te vermelden krachtens welk wettelijk voorschrift de beschikking op bezwaar is genomen.

66 Zie o.a. Gea Curaçao 1 september 2011, ECLI:NL:OGEAC:2017:BR6709 (Isla).

67 Art. 3:47 lid 3, 3:48 en 3:50 Awb.

68 Art. 3:49 Awb.

69 Art. 50a Lar (in 2015 ingevoegd). Vgl. art. 6:22 Awb.

70 Zie art. 3:3 Awb. Vgl. R.J.N. Schlössels en S.E. Zijlstra, Bestuursrecht in de sociale rechtsstaat, Deventer: Wolters Kluwer 2017, p. 2014-2017. 
1984 in het geval van de verblijfsvergunning voor de dienstbode van de heer Staartjes. Deze dienstbode had een verblijfsvergunning verkregen onder de voorwaarde dat zij bij haar werkgever zou inwonen. Toen zij na haar eerste werkgever vervolgens bij Staartjes in dienst trad, kreeg zij te horen dat er 'geen dringende noodzaak tot inwoning aanwezig was, mede gelet op de heersende werkloosheid' en werd de aanpassing van haar verblijfsvergunning voor haar indiensttreding bij Staartjes geweigerd. De rechter achtte deze weigering in strijd met het doel van de vreemdelingenwetgeving en daarmee in strijd met het verbod van détournement de pouvoir. ${ }^{71}$

Het materiële zorgvuldigheidsbeginsel eist dat alle relevante belangen die ten behoeve van het besluit zijn verzameld en in de besluitvorming zijn betrokken (formele zorgvuldigheidsbeginsel, zie hiervoor) op een zorgvuldige wijze worden afgewogen. ${ }^{72}$ Nauw verwant aan het materiele zorgvuldigheidsbeginsel zijn het evenredigheidsbeginsel en het verbod van willekeur. Het evenredigheidsbeginsel eist dat de voor één of meer belanghebbenden nadelige gevolgen van een besluit niet onevenredig mogen zijn in verhouding tot de met het besluit te dienen doelen. In Curaçao is dat laatste beginsel te vinden in Regeling Ambtenarenrechtspraak. ${ }^{73}$ Voor het overige kan de Awb analoog worden toegepast. Het beginsel impliceert mede dat daar waar de nadelige gevolgen onevenredig zijn, ter compensatie schadevergoeding dient te worden verstrekt aan hen die onevenredig worden getroffen (egalité devant les charges publiques) en dat dient te worden afgeweken van beleidsregels, indien deze voor één of meer belanghebbenden gevolgen hebben die wegens bijzondere omstandigheden onevenredig zijn in verhouding tot de met die beleidsregels te dienen doelen. ${ }^{74}$ Het beginsel speelt verder vooral een rol bij sancties. ${ }^{75}$ De belangenafweging mag ook niet in strijd zijn met het verbod van willekeur. Dat is het geval, indien het bestuursorgaan bij afweging van de betrokken belangen niet in redelijkheid tot het besluit heeft kunnen komen. Het bestuursorgaan moet, gelet op het verbod van willekeur, blijven binnen de marges van wat niet-onredelijk kan worden genoemd. Deze norm is vooral een toetsingsnorm voor de rechter. Daarom wordt de toetsing die de rechter aan de hand van het verbod van willekeur verricht ook wel marginale (beleids)toetsing genoemd. ${ }^{76}$ Een voorbeeld waaruit blijkt dat ook de rechter in Curaçao zich daaraan gebonden acht betrof de verwijdering van twee leerkrachten uit Curaçao door de minister van Justitie, omdat de leerkrachten zich niet hadden gehouden aan de voorwaarde dat zij gedurende de beroepsprocedure over hun verblijfsvergunning niet zouden werken. De rechter overwoog dat bij de hantering van die bevoegdheid tot verwijdering aan het belang van de leerkrachten kennelijk te weinig waarde is gehecht en concludeerde dat de minister bij een richtige belangenafweging, mede gelet op diens tolerante houding ten aanzien van anderen in het verleden, in redelijkheid niet tot de voorgenomen beslissing had kunnen komen. ${ }^{77}$

GHvJ 13 maart 1984, TAR-Justicia Jurisprudentie Bestuursrecht 1998, p. 58-63 (Inwonende dienstbode van Staartjes). Art. 3:4 lid 2 Awb.

Vgl. art. 35 lid 2 Regeling Ambtenarenrechtspraak en art. 3:4 lid 2 Awb.

Art. 4:84 Awb. GHvJ 22 november 2016, ECLI:NL:OGHACMB:2016:191.

Zie de hiervoor reeds genoemde uitspraak van de burgerlijke rechter van het Gea Curaçao van 15 augustus 1997, TAR-Justicia 1998, afl. 3, p. 179-183, JB 1998 p. 76-81 (Godett).

Zie daarover ABRvS 9 mei 1996, AB 1997/93 en JB 1997/158 (Maxis \& Praxis).

GHvJ 1 april 1986, TAR-Justicia Jurisprudentie Bestuursrecht, december 1998, p. 144-147. 


\subsection{Algemene beginselen van behoorlijk procesrecht en procesregels}

Veel regels van bestuursprocesrecht in de Lar zijn identiek of vrijwel identiek aan regels in de Awb. Zo is bijvoorbeeld de beroepstermijn in de Lar gelijk aan die in de Awb: zes weken. ${ }^{78}$ Leemten in de Curaçaose proceswetgeving kunnen worden opgevuld door analoge toepassing van (aanvullende) procesregels uit de Awb, behalve waar het gaat om bevoegdheden, rechten, verplichtingen of aanspraken. Zo mag worden verondersteld dat getuigen en deskundigen in de bezwaarfase niet alleen door het bestuursorgaan voor een hoorzitting kunnen worden uitgenodigd, ${ }^{79}$ maar dat zij op verzoek van de belanghebbende ook kunnen worden gehoord, al staat dat niet in de Lar. ${ }^{80}$ Anderzijds kan van het recht van een belanghebbende om in de bezwaarfase te worden gehoord niet worden afgezien als de belanghebbende niet binnen een door het bestuursorgaan gestelde redelijke termijn verklaart dat hij gebruik wil maken van het recht te worden gehoord. ${ }^{81}$ Deze regel ontbreekt ook in de Lar.

Per saldo zijn er verder maar weinig procesregels die wel in de Awb zijn opgenomen en niet in de Lar, die analoog in Curaçao kunnen worden toegepast. Richtinggevend voor analoge toepassing is of rechtsregels, ook voordat ze in de Awb waren opgenomen, reeds als ongeschreven recht waren aanvaard. In die gevallen is goed verdedigbaar dat deze regels ook als ongeschreven recht in Curaçao hebben te gelden. Zo is bij een herhaalde aanvraag van een beschikking de aanvrager gehouden nieuw gebleken feiten of veranderde omstandigheden te vermelden. ${ }^{82}$ En het bestuursorgaan blijft verplicht een besluit te nemen, indien een beroep zich richt tegen het niet tijdig nemen van een besluit, tenzij de belanghebbende daarbij als gevolg van de beslissing op het beroep geen belang meer heeft. ${ }^{83}$ Deze regel geldt, hoewel daar niet opgeschreven, ook in Curaçao, maar de naleving daarvan kan in rechte slechts bij de burgerlijke rechter worden afgedwongen. ${ }^{84}$ Verder spreekt het ook vanzelf dat onder de Lar een bezwaar- of beroepschrift tijdig is ingediend, indien het voor het einde van de termijn is ontvangen. ${ }^{85}$ En in de Awb is ten overvloede bepaald dat het bezwaar of beroep niet de werking van het besluit waartegen het is gericht schorst, tenzij bij of krachtens wettelijk voorschrift anders is bepaald. ${ }^{86}$ Deze hoofdregel van bestuursprocesrecht is zowel in de oude wetgeving als in de literatuur en de rechtspraak aanvaard en geldt ook voor bezwaar en beroep tegen beschikkingen in Curaçao. Het spreekt verder vanzelf dat, indien iemand zich laat vertegenwoordigen, de stukken (ook) in de bezwaarfase aan de gemachtigde worden gestuurd, al staat dat niet in de Lar. ${ }^{87}$ Ook de regel dat bezwaar en beroep kunnen worden ingetrokken is niet expliciet in de Lar opge-

78 Art. 16 lid 1 en 56 lid 1 Lar. Art. 6:7 Awb.

79 Art. 65 lid 1 Lar.

80 Art. 7:8 Awb.

81 Art. 7:3 aanhef en sub d Awb (de zgn. 'antwoordkaartmethode').

82 Vgl. art. 4:6 Awb en GHvJ 28 mei 2012, ECLI:NL:OGHACMB:2012:BW8365.

83 Art. 6:20 lid $1 \mathrm{Awb}$.

84 GHvj 23 mei 2014, HLAR 63251/14 en 66649/14, CJB 2014, afl. 2, p. 108-119, m.nt. Rogier en GHvJ 26 juli 2016, ECLI:NL:OGHACMB:2016:89.

85 Art. 6:9 lid 1 Awb. De regel van art. 6:9 lid 2 Awb (inzake verzending per post) kan niet analoog worden toegepast.

86 Art. 6:16 Awb.

87 Art. 6:17 Awb. 
nomen, maar de Lar gaat wel uit van de mogelijkheid daartoe. ${ }^{88}$ Het lijkt, gelet op het actus contrarius-beginsel, ${ }^{89}$ verdedigbaar dat in Curaçao naar analogie geldt dat dat schriftelijk dient te geschieden en dat het recht om mondeling in te trekken alleen is toegestaan tijdens het horen. ${ }^{90}$ Tot slot lijkt het verdedigbaar dat de regel voor herstel van verzuim bij het instellen van bezwaar en beroep ${ }^{91}$ in Curaçao analoog wordt toegepast in situaties waarin het elektronisch uitwisselen van stukken met het bestuur of de rechter op bezwaren stuit.

\section{Geen analoge toepassing van de Awb}

Zoals hiervoor vermeld, ligt analoge toepassing van de Awb niet in de rede als het gaat om bevoegdheden en verplichtingen van bestuursorganen en van de rechter en bij rechten, verplichtingen en aanspraken van burgers.

Veel regels over bevoegdheden, rechten, verplichtingen en aanspraken zijn op identieke wijze of vrijwel identieke wijze opgenomen in de Lar. Dat is ook uitdrukkelijk de bedoeling geweest van de Lar-wetgever. Van een bewuste afwijking van de Awb is in het Curaçaose bestuursrecht nauwelijks sprake. Slechts op een enkel punt heeft de Lar-wetgever bewust willen afwijken van de Awb. In die gevallen kunnen Awb-regels niet analoog worden toegepast. ${ }^{92}$ Voor het overige zijn de in Curaçao bestaande afwijkingen van de Awb eerder het gevolg van een achterstand in rechtsontwikkeling.

Hierna komen achtereenvolgens de niet-analoog toe te passen bevoegdheden en verplichtingen van bestuursorganen en van de rechter, en verplichtingen, rechten en aanspraken van burgers aan de orde. Bestuursorganen en rechters bezitten geen aanspraken en burgers hebben geen (publiekrechtelijke) bevoegdheden.

\subsection{Bevoegdheden en verplichtingen van bestuursorganen}

Analoge toepassing van Awb-regels is niet toegestaan waar de Awb bevoegdheden toekent aan bestuursorganen of hun daarbij beperkingen of verplichtingen oplegt. Zo bestaat er in Curaçao geen wettelijke bevoegdheidsgrondslag voor het vaststellen van beleidsregels, althans beleidsregels met alle kenmerken die de Awb daaraan toekent, zoals de verplichting om bij het vaststellen van beleidsregels het wettelijk voorschrift te noemen waaruit de beleidsregel voortvloeit. ${ }^{93}$ Dat neemt niet weg dat bestuursorganen in Curaçao hun beleid op schrift kunnen stellen en dat burgers hen daaraan via het vertrouwensbeginsel kunnen houden.

Verder is in de Lar de uiterste termijn voor het nemen van beschikkingen door het bestuur - voor zover deze niet in bijzondere wetgeving is bepaald - opengelaten, terwijl in de Awb

89 Op grond van het actus contrarius-beginsel gelden bij de intrekking van de beschikking dezelfde vereisten als bij de aanvraag.

90 Art. 6:21 Awb. Zie art. 17 lid 6 en 50 lid 10 Lar waar de intrekking wel wordt genoemd.

91 Art. 6:6 aanhef en onder b Awb. Vgl. art. 22 Lar. Overigens maakt art. 85 lid 3 Vreemdelingenwet 2000 daar een uitzondering op voor beroepschriften in hoger beroep in vreemdelingenzaken. Deze uitzondering kan niet analoog worden toegepast bij het instellen van hoger beroep in vreemdelingenzaken in Curaçao.

92 Vgl. Drop 2014, p. 340.

93 Vgl. art. 1:3 lid 4 en Titel 4.3 Awb. 
die uiterste termijn is bepaald op acht weken na ontvangst van de aanvraag van een beschikking. ${ }^{94}$ Een analoge toepassing van de Awb ligt, gezien de keuze van de Lar-wetgever om die termijn open te laten, hier niet voor de hand. ${ }^{95}$ Ook de wettelijke termijnen voor het nemen van een beslissing op bezwaar in de Lar verschillen van die in de Awb. ${ }^{96}$

De bevoegdheid tot het invorderen van een verbeurde dwangsom verjaart in Curaçao niet (standaard) na verloop van een jaar. ${ }^{97}$ En de bevoegdheid tot het opleggen van een bestuurlijke boete is niet aan algemene verjaringstermijnen gebonden. ${ }^{98}$ Verder heeft een Curaçaos bestuursorgaan, dat beschikt over de bevoegdheid tot toepassing van bestuursdwang, niet automatisch ook de bevoegdheid tot het opleggen van een last onder dwangsom ${ }^{99}$ en heeft het bij de uitoefening van bestuursdwang niet het recht zaken mee te voeren en op te slaan. ${ }^{100}$ Ook bestaat er in Curaçao geen algemene regel die inhoudt dat aan degene die wordt verhoord met het oog op het opleggen van een boete, wordt meegedeeld dat hij niet tot antwoorden verplicht is (de cautie). ${ }^{101}$ En in Curaçao heeft een bestuursorgaan, wanneer het een subsidie heeft verstrekt en deze subsidie heeft geleid tot vermogensvorming, niet automatisch recht op een vergoeding. ${ }^{102}$ De Awb-regels over deze onderwerpen zijn in Curaçao niet analoog van toepassing.

Mandaat behoeft, zoals gezegd, geen wettelijke grondslag. De Awb verbiedt mandaat bij het vaststellen van algemeen verbindende voorschriften, bij het nemen van besluiten die met versterkte meerderheid moeten worden genomen of waarvan de aard van de voorgeschreven besluitvorming zich anderszins tegen mandaatverlening verzet, bij het vernietigen van of het onthouden van goedkeuring aan een besluit van een ander bestuursorgaan en bij het opleggen van een bestuurlijke boete aan degene die rapport of proces-verbaal van de overtreding heeft opgemaakt. ${ }^{103}$ Hoewel analoge toepassing van de regel dat geen mandaat mogelijk is wanneer de aard van de bevoegdheid zich daartegen verzet, ${ }^{104}$ in Curaçao verdedigbaar is, staat analoge toepassing van de meer specifiek in de Awb aangegeven gevallen van het mandaatverbod geenszins vast. ${ }^{105}$ Evenmin staat vast dat in Curaçao mandaat, zoals de Awb voorschrijft, niet kan worden verleend aan een niet-ondergeschikte zonder diens toestemming en de toestemming van degene onder wiens verantwoordelijkheid hij werkt, ${ }^{106}$ al ligt dat natuurlijk in de rede. Maar dat de gemandateerde in Curaçao zonder

94 Art. 4:13 lid 2 Awb.

95 Vgl. Zijlstra 2015, p. 273. Zie voor de gevolgen die het ontbreken van een beslistermijn heeft voor het indienen van bezwaar of beroep De Haseth 2016, p. 5-6.

96 Art. 68 lid 1 Lar en art. 7:10 Awb.

97 Art. 5:35 Awb.

98 Art. 5:45 Awb.

99 Art. 5:32 lid 1 Awb.

100 Art. 5:29 Awb.

101 Art. 5:10a Awb.

102 Art. 4:41 lid 3 Awb.

103 Art. 10:3 Awb.

104 Zie par. 3 in deze bijdrage.

$105 \mathrm{Zo}$ is bijvoorbeeld niet uitgesloten dat in Curaçao krachtens mandaat op een bezwaarschrift kan worden beslist door dezelfde gemandateerde die ook in primo heeft beslist. Zie GHvJ 18 juni 2009, ECLI:NL: OGHNAA:2009:BJ5755 (Setel).

106 Art. 10:4 Awb. 
meer gehouden zou zijn de mandaatgever op diens verzoek inlichtingen te verschaffen over de uitoefening van de bevoegdheid, ${ }^{107}$ is niet vanzelfsprekend. Volgens de Awb moet algemeen mandaat schriftelijk worden verleend; mandaat voor een bepaald geval mag mondeling. Het Gemeenschappelijk Hof van Justitie is op dat punt zelfs strenger: alle mandaat moet schriftelijk worden verleend, ${ }^{108}$ maar de verplichting die in de Awb staat, ${ }^{109}$ om mandaatbesluiten te publiceren, geldt niet in Curaçao. Evenmin zijn de in de Awb opgenomen verplichtingen voor het bestuur om in het krachtens mandaat genomen besluit te vermelden namens welk bestuursorgaan het besluit is genomen en om de regels voor mandaat ook bij volmacht tot het verrichten van privaatrechtelijke rechtshandelingen en machtiging tot het verrichten van andere handelingen toe te passen, ${ }^{110}$ analoog van toepassing in Curaçao.

Ten aanzien van delegatie ${ }^{111}$ geldt in Curaçao niet vanzelfsprekend de in de Awb opgenomen regels dat delegatie aan ondergeschikten verboden is, ${ }^{112}$ dat het delegerende bestuursorgaan aan degene aan wie de bevoegdheid is gedelegeerd alleen instructies kan geven middels beleidsregels en dat degene aan wie de bevoegdheid is gedelegeerd verplicht is het delegerende bestuursorgaan op diens verzoek inlichtingen te verschaffen over de uitoefening van de bevoegdheid. ${ }^{113}$ Dat geldt ook voor de verplichting om in het besluit, dat op grond van een gedelegeerde bevoegdheid is genomen, het delegatiebesluit en de vindplaats daarvan te vermelden. ${ }^{114}$ De schakelbepaling in de Awb krachtens welke ook delegatie door een bestuursorgaan mogelijk is van een bevoegdheid van een ander bestuursorgaan aan een derde (allodelegatie) ${ }^{115}$ en de bepaling die de regels voor delegatie ook bij volmacht tot het verrichten van privaatrechtelijke rechtshandelingen en machtiging tot het verrichten van andere handelingen van overeenkomstige toepassing verklaart, ${ }^{116}$ zijn evenmin analoog van toepassing in Curaçao.

De Awb-regels over de bekendmaking van andere besluiten dan beschikkingen kunnen in Curaçao niet analoog worden toegepast. ${ }^{117}$ In Curaçao is een Bekendmakingsverordening van kracht. ${ }^{118}$ Daarin is bepaald dat alle vormen van regelgeving worden bekendgemaakt in het Publicatieblad en alle andere officiële berichten en bekendmakingen die landsorganen aan het publiek willen mededelen in de Curaçaosche Courant.

Ten slotte bevat de Awb voor bestuursorganen bepalingen over een aantal bijzondere onderwerpen die in Curaçao niet in algemene zin zijn geregeld. Deze bepalingen zijn ook

107 Art. 10:6 lid 2 Awb.

108 GHvJ 28 juni 2013, ECLI:NL:OGHACMB:2013:42 (Schriftelijk mandaat).

109 Een mandaatbesluit is een besluit in de zin van de Awb en dient uit dien hoofde te worden bekendgemaakt conform art. 3:40 e.v. Awb.

110 Art. 10:10 en 10:12 Awb.

111 Zie daarover ook par. 3 in deze bijdrage.

112 Art. 10:14 Awb.

113 Art. 10:16 Awb.

114 Art. 10:19 Awb.

115 Art. 10:20 Awb.

116 Art. 10:21 Awb.

117 Art. 3:42-3:45 Awb. Zie over de bekendmaking van beschikkingen par. 3.4 in deze bijdrage.

118 Bekenmakingsverordening, bijlage bij AB 2010, nr. 87. 
niet analoog toe te passen in Curaçao. Zo bevat de regeling omtrent advisering bepalingen over adviezen van bij wettelijk voorschrift ingestelde personen of colleges die bestuursorganen bij het nemen van besluiten dienen te betrekken. ${ }^{119}$ De regeling inzake samenhangende besluiten legt aan bestuursorganen de verplichting op om te bevorderen dat een aanvrager in kennis wordt gesteld van andere op de aanvraag te nemen besluiten, waarvan het bestuursorgaan redelijkerwijs kan aannemen dat deze nodig zijn voor de door de aanvrager te verrichten activiteit. ${ }^{120}$ De regeling van de dwangsom bij niet tijdig beschikken strekt ertoe dat het bestuursorgaan een dwangsom verbeurt aan de aanvrager van een beschikking voor elke dag dat het in gebreke is. Het bestuursorgaan stelt zelf de verschuldigdheid en de hoogte van de dwangsom bij beschikking vast. ${ }^{121}$ De regeling van de positieve beschikking bij niet tijdig beslissen (lex silencio positivo) strekt ertoe dat, indien niet tijdig op de aanvraag tot het geven van een beschikking is beslist, de gevraagde beschikking van rechtswege is gegeven. ${ }^{122}$ Ten aanzien van publiekrechtelijke geldschulden kent de Awb aan bestuursorganen bijzondere publiekrechtelijke bevoegdheden toe, zoals het vaststellen van de verplichting tot betaling van een geldsom en de bevoegdheid tot het uitvaardigen van een dwangbevel dat ertoe strekt de betaling van een geldsom af te dwingen. ${ }^{123}$ De regeling van de klachtenbehandeling door een bestuursorgaan geeft niet alleen aan eenieder het recht een klacht in te dienen over de wijze waarop een bestuursorgaan zich in een bepaalde aangelegenheid jegens hem of een ander heeft gedragen, maar schrijft ook voor hoe dat bestuursorgaan die klacht dient te behandelen. ${ }^{124}$ In Curaçao bestaat geen algemene regeling over klachtenbehandeling, maar het recht om een klacht in te dienen en daarop antwoord te krijgen valt wel onder het petitierecht. ${ }^{125}$

\subsection{Bevoegdheden en verplichtingen van de rechter}

De bestuursrechter is in de eerste plaats gehouden een (hoger) beroep in behandeling te nemen en bevoegd om daarover een bindende uitspraak te doen. Zijn competentie wordt in Nederland bepaald door het besluitbegrip en in Curaçao door het beschikkingsbegrip. Het Hof oordeelt streng waar het gaat om de uitoefening van rechterlijke bevoegdheden. ${ }^{26}$ Het ligt dan ook niet voor de hand dat de Awb-regels over de rechterlijke competentie analoog van toepassing zijn in Curaçao, behalve waar die geheel identiek zijn. De dicta in eerste aanleg zijn in de Awb en in de Lar identiek. ${ }^{127}$ Verder komt ook de inhoud van de uitspraak grotendeels overeen. ${ }^{128}$ De competentie van de hogerberoepsrechters is echter niet helemaal identiek geregeld. ${ }^{129}$ Ook wat de uitspraakbevoegdheid in hoger beroep betreft zijn de afwijkingen groter. ${ }^{130}$ Zo ontbreekt in de Lar de regel dat als de uitspraak in hoger

119 Afdeling 3.3, i.h.b. art. 3:5 Awb.

120 Afdeling 3.5 Awb.

121 Par. 4.1.3.2, i.h.b. art. 4:17 en 4:18 Awb.

122 Par. 4.1.3, i.h.b. art. 4:20b lid 1 en 4:20c lid 1 Awb.

123 Titel 4.4, i.h.b. art. 4:86 en 4:115 Awb.

124 Titel 9.1, i.h.b. art. 9.1 en Afdeling 9.1.2 Awb.

125 Art. 7 Staatsregeling van Curaçao.

126 Drop 2014, p. 341.

127 Art. 8:70 Awb en art. 50 lid 1 Lar.

128 Art. 8:77 Awb en art. 49 Lar.

129 Vgl. art. 8:104 Awb en art. 75 Lar.

130 Vgl. art. 8:113-8:118 Awb en art. 78-78e Lar. 
beroep ertoe strekt dat het bestuursorgaan een nieuw besluit neemt, de uitspraak tevens kan inhouden dat beroep tegen dat besluit slechts kan worden ingesteld bij de hogerberoepsrechter. ${ }^{131}$

Bij de behandeling van het (hoger) beroep is de rechter bevoegd een aantal procesbeslissingen te nemen. De regels daarvoor in de Lar komen grotendeels overeen met die in de Awb, maar niet allemaal. En omdat het om bevoegdheden gaat kunnen de Awb-regels niet analoog worden toegepast. Zo kan op grond van de Awb in een zaak die in behandeling is in hoger beroep, aan een lid van het desbetreffende hogerberoepscollege gevraagd worden een conclusie te nemen. ${ }^{132}$ Dat is in Curaçao (nog) niet mogelijk. En op grond van de Awb kan de bestuursrechter, anders dan op grond van de Lar, een persoon - niet zijnde een advocaat - tegen wie ernstige bezwaren bestaan weigeren een partij bijstand te verlenen of deze te vertegenwoordigen. ${ }^{133}$ Verder kan de bestuursrechter op grond van de Awb de griffier opdragen een onderzoek ter plaatse in te stellen (descente). ${ }^{134}$ Dat is in Curaçao niet mogelijk. De Curaçaose bestuursrechter is ook niet bevoegd tot toepassing van de zogenoemde 'bestuurlijke lus ${ }^{\prime 35}$ noch tot het doen van tussenuitspraken. ${ }^{136}$ Verder heeft de Curaçaose bestuursrechter niet dezelfde bevoegdheid als de Nederlandse bestuursrechter waar het gaat om het 'terugsturen' van het beroepschrift naar de bezwaarfase. ${ }^{137}$ Op grond van de Awb moet het bestuursorgaan in dat geval het beroepschrift als bezwaarschrift behandelen. Op grond van de Lar kan het Gerecht het beroepschrift alleen naar het bestuursorgaan sturen met het verzoek of het bereid is de beschikking in heroverweging te nemen. ${ }^{138}$ Daar beslist derhalve het bestuursorgaan of de bezwaarfase wordt gevolgd. Voorts is de bestuursrechter, indien hij een boetebeschikking vernietigt, op grond van de Awb, anders dan op grond van de Lar, verplicht de zaak zelf af te doen. ${ }^{139}$ Ook is de bestuursrechter op grond van de Awb bevoegd op verzoek van de belanghebbende een bestuursorgaan bij onrechtmatig handelen of besluiten te veroordelen tot vergoeding van schade. ${ }^{140}$ De Lar voorziet niet in deze zelfstandige procedure tot schadevergoeding. Zij voorziet wel in de mogelijkheid tot het toekennen van schadevergoeding door de rechter in het kader van de procedure tegen de schadeveroorzakende beschikking (accessoire schadevergoeding $)^{141}$ en zij laat de mogelijkheid open om een zuivere schadebeschikking te vragen aan het bestuur ten aanzien van onrechtmatige én rechtmatige beschikkingen. Verder wijkt in hoger beroep de analoge toepassing van het procesrecht in eerste aanleg in de Awb op onderdelen af van die in de Lar. ${ }^{142}$ Ten slotte kent de Awb, anders dan de Lar, in hoger beroep de mogelijkheid van het instellen van incidenteel hoger beroep. ${ }^{143}$ Een

131 Art. 8:113 lid 2 Awb.

132 Art. 8:12a Awb.

133 Art. 8:25 Awb.

134 Art. 8:51 Awb.

135 Art. 8:51a -8:51d Awb.

136 Art. 8:80a en 8:80b Awb.

137 Art. 8:54a Awb.

138 Art. 54 Lar.

139 Art. 8:72a Awb.

140 Art. 8:88-8:95 Awb.

141 Art. 50 lid 5 en 6 Lar.

142 Vgl. art. 8:108 Awb en art. 77 Lar.

143 Art. 8:110-8:112 Awb. 
opvallend omgekeerd verschil is dat de rechter op grond van de Awb niet en op grond van de Lar wel kan bevelen dat partijen 'met de sterke arm' voor hem worden gebracht. ${ }^{144}$

De Awb voorziet naast bevoegdheden ook in een aantal verplichtingen voor de bestuursrechter, die deels door de griffie(r) worden vervuld, zoals het verstrekken van een ontvangstbevestiging van het beroepschrift, het zo nodig doorzenden daarvan naar het juiste orgaan en de verplichting tot motivering van de uitspraak. ${ }^{145}$ Deze verplichtingen komen in de Awb en in de Lar in hoge mate overeen. Afwijkend is dat in Curaçao voor de rechter, evenmin als voor het bestuursorgaan, ${ }^{146}$ de verplichting bestaat dat hij in een procedure over een bestuurlijke boete aan de partij, waaraan een bestuurlijke boete is opgelegd, dient mede te delen dat deze niet tot antwoorden verplicht is (de cautie). ${ }^{147}$ Een andere belangrijke Awb-regel die (nog) niet in de Lar is te vinden betreft het relativiteitsvereiste. De rechter is gehouden een besluit niet te vernietigen op de grond dat het in strijd is met een geschreven of ongeschreven regel of een algemeen rechtsbeginsel, indien deze regel of dit beginsel kennelijk niet strekt tot bescherming van de belangen van degene die zich daarop beroept. ${ }^{148}$ Het Curaçaose bestuursrecht kent dit relativiteitsvereiste niet. ${ }^{149}$

\subsection{Rechten, verplichtingen en aanspraken van burgers}

De Awb en de Lar verlenen aan burgers rechten en aanspraken en leggen hun verplichtingen op die grotendeel overeenkomen, maar niet allemaal identiek zijn. Rechten en aanspraken van burgers zijn meestal het spiegelbeeld van verplichtingen van overheidsorganen.

\subsubsection{Rechten}

De in de Awb voor het bestuur geformuleerde verplichting om in het bestuurlijk verkeer de Nederlandse taal te gebruiken ${ }^{150}$ en het daaruit af te leiden recht voor burgers om in die taal te worden benaderd, is niet analoog van toepassing in Curaçao. Voor de rechtstaal bestaan in Curaçao algemene regels. ${ }^{151}$ Ten aanzien van de aanvang van het recht om een bezwaar- en beroepschrift in te dienen gelden op grond van de Awb bijzondere regels voor besluiten waartegen alleen door één of meer bepaalde belanghebbenden administratief beroep kan worden ingesteld, die aan goedkeuring zijn onderworpen en die zijn voorbereid met een uitgebreide openbare voorbereidingsprocedure. ${ }^{152}$ Deze regels zijn niet analoog van toepassing in Curaçao. In de Lar is voorts geen uiterste termijn opgenomen waarbinnen in de bezwaarfase stukken kunnen worden ingediend, voordat de hoorzitting wordt gehouden. In de Awb is bepaald dat tot tien dagen voor het horen belanghebbenden

144 Art. 8:31 Awb en art. 39 Lar.

145 Art. 6:14, 6:15 en 8:77 lid 1 sub b Awb en art. 20 lid 1 en 2 en 49 lid 1 Lar.

146 Zie par. 4.1 in deze bijdrage.

147 Art. 8:28a Awb.

148 Art. 8:69a Awb. Vgl. art. 6:22 Awb en art. 50a, de pendant daarvan in de Lar. Zie daarover hiervoor par. 3.2.

149 Vgl. GHvJ 8 mei 2017, ECLI:NL:OGHACMB:2017:88.

150 Art. 2:6 Awb.

151 De Landsverordening officiële talen (PB 2007, nr. 20) en art. 9 Rijkswet Gemeenschappelijk Hof van Justitie: Engels, Nederlands en Papiaments.

152 Art. 6:8 lid 2-4 Awb. 
nader stukken kunnen indienen. ${ }^{153}$ Deze termijn is niet analoog toepasbaar in Curaçao. Wel is in de Lar bepaald dat tijdens de hoorzitting geen nieuwe stukken kunnen worden overgelegd, indien de andere partijen of hun gemachtigden daartegen bezwaar maken. ${ }^{154}$ De Lar voorziet, anders dan de Awb, niet in de mogelijkheid dat belanghebbenden in bezwaar afzonderlijk worden gehoord, indien aannemelijk is dat gezamenlijk horen een zorgvuldige behandeling zal belemmeren of dat tijdens het horen feiten of omstandigheden bekend zullen worden, waarvan geheimhouding om gewichtige reden is gebleken. ${ }^{155}$ In afwijking van de Awb kan een belanghebbende in Curaçao het recht om beroep in te stellen niet worden ontzegd, indien hem redelijkerwijze kan worden verweten dat hij geen zienswijze naar voren heeft gebracht of geen bezwaar heeft gemaakt, behalve in gevallen waarin het indienen van een bezwaarschrift verplicht is gesteld. ${ }^{156}$ Expliciet afwijkend van de Awb is ook de termijn waarbinnen partijen het recht hebben om nadere stukken in te dienen bij de behandeling van het beroep. In de Awb is die termijn bepaald op tien dagen voor de zitting; in de Lar is deze termijn zeven dagen. ${ }^{157}$ Voorts staat in afwijking van de Awb het recht om schorsing en voorlopige voorziening te vragen op grond van de Lar alleen open voor de indiener van een bezwaar- of beroepschrift, maar de rechter heeft het ook opengesteld voor andere belanghebbenden en daarmee de Awb analoog toegepast. ${ }^{158}$ Strikt genomen kunnen derden zich ook niet voegen in een voorlopige voorziening (vovo)-procedure en naar voren brengen dat zij onevenredig nadeel lijden van de onmiddellijke uitvoering van de beschikking, omdat de door de rechter te verrichten afweging alleen ziet op evenredig nadeel voor de indiener van het vovo-verzoek. ${ }^{159}$ Maar ook hier is door de rechter in de praktijk aan voorbijgegaan. ${ }^{160}$ Verder heeft een burger in Curaçao niet het recht om een verzoekschrift in te dienen bij de rechter ter verkrijging van schadevergoeding bij onrechtmatig handelen van het bestuur ${ }^{161}$ of om incidenteel hoger beroep in te stellen. ${ }^{162}$ Ten slotte bestaat, zoals gezegd, in Curaçao weliswaar het recht van petitie, ${ }^{163}$ maar geen algemene regeling over de behandeling van klachten over de wijze waarop een bestuursorgaan zich in een bepaalde aangelegenheid heeft gedragen. ${ }^{164}$

\subsubsection{Verplichtingen}

Een algemene verplichting tot geheimhouding voor eenieder die betrokken is bij de uitvoering van de taak door een bestuursorgaan, zoals opgenomen in de Awb, ${ }^{165}$ ontbreekt in

153 Art. 7:4 lid 1 Awb.

154 Art. 64 lid 5 Lar.

155 Art. 7:6 lid 2 Awb.

156 Vgl. art. 6:13 Awb. Bezwaar is in Curaçao verplicht gesteld in het belastingrecht (zie GHvJ 7december 2016, ECLI:NL:OGHACMB:2016:180) en in art. 12 Landsverordening arbeid vreemdelingen.

157 Art. 8:58 lid 2 Awb en art. 27 lid 4 Lar.

158 Art. 85 Lar en art. 8:81 Awb. GHvJ 25 april 2012, ECLI:NL:OGHACMB:2012:BX0144.

159 Art. 26 Lar is niet van toepassing in het kader van een vovo op grond van de Lar. Vgl. art. 8:81 lid 1 Awb waar gesproken wordt van de 'betrokken belangen'.

160 Gea Curaçao 1 december 2017, Lar:CUR201702346 en Lar:CUR201702365.

161 Art. 8:88 Awb.

162 Art. 8:110 Awb.

163 Art. 7 Staatsregeling van Curaçao.

164 Titel 9.1 Awb.

165 Art. 2:5 Awb. 
Curaçao, behalve voor ambtenaren. ${ }^{166}$ In afwijking van de Awb ontbreekt in de Lar ook de verplichting voor de indiener om zorg te dragen voor een vertaling van het bezwaar- of beroepschrift, indien dat voor een goede behandeling van het bezwaar of beroep noodzakelijk is. ${ }^{167}$ En partijen zijn niet, zoals in Nederland, verplicht om in persoon te verschijnen, als zij door de bestuursrechter zijn opgeroepen. ${ }^{168}$ In afwijking van de Awb kent de Lar ook geen verplichting voor partijen om mee te werken aan een onderzoek door een deskundige. ${ }^{169}$

\subsubsection{Aanspraken}

De aanvrager van een beschikking heeft op grond van de Awb aanspraak op een dwangsom bij niet tijdig beschikken. ${ }^{170}$ Deze regel is in Curaçao niet analoog van toepassing. Dat geldt ook voor de regel dat de rechter kan bepalen dat ook in andere gevallen dan wanneer het beroep gegrond is verklaard het griffierecht door het bestuursorgaan geheel of gedeeltelijk wordt vergoed. ${ }^{171}$ Maar ook ten aanzien daarvan heeft de rechter zich coulant opgesteld door te bepalen dat griffierecht wordt terugbetaald als een rechtsmiddel niet-ontvankelijk wordt verklaard, omdat het bestuursorgaan geheel aan de bezwaren van de belanghebbende is tegemoetgekomen. ${ }^{172}$

\section{Samenvatting}

De Algemene wet bestuursrecht is een Nederlandse wet die niet van kracht is in Curaçao. Maar in Curaçao wordt daar wel vaak een beroep op gedaan. Met de Awb wordt veelal nader betekenis gegeven aan bestuursrechtelijke regels en begrippen die in Curaçao niet zijn opgeschreven of veel minder zijn uitgewerkt. Curaçaose regelgeving die (vrijwel) gelijkluidend is aan de Nederlandse regelgeving wordt analoog toegepast. In de rechtspraak komt dat duidelijk tot uitdrukking.

Van een bewuste afwijking van de Awb is in het Curaçaose bestuursrecht nauwelijks sprake. Slechts op een enkel punt heeft de Lar-wetgever bewust willen afwijken van de Awb. Voor het overige zijn de in Curaçao bestaande afwijkingen van de Awb eerder het gevolg van een achterstand in rechtsontwikkeling. Regelgeving die in Nederland al wel, maar in Curaçao nog niet is gemoderniseerd, wordt veelal toch analoog toegepast. En verder is het mogelijk dat (delen van ) regels die niet in de Lar, maar wel in de Awb staan, als ongeschreven recht in Curaçao gelden. Daarbij gaat het vaak om begripsomschrijvingen en algemene rechtsbeginselen, waaronder beginselen van behoorlijk bestuur en beginselen van behoorlijk procesrecht.

166 Art. 62 Landsverordening Materieel Ambtenarenrecht.

167 Art. 6:5 lid 3 Awb.

168 Art. 8:27 Awb.

169 Art. 8:30 Awb. De Haseth noemt dat een 'opvallende lacune' (De Haseth e.a. 2016, p. 130).

170 Art. 4:17 Awb.

171 Art. 8:74 lid 2 Awb.

172 GHvJ 8 december 2016, ECLI:NL:OGHACMB:2016:165. 
Maar analoge toepassing heeft ook grenzen. Een belangrijke beperking voor analoge toepassing vormt het legaliteitsvereiste. Voor de toedeling van bevoegdheden aan een bestuursorgaan of aan de rechter, of van rechten, verplichtingen of aanspraken van burgers is een expliciete wettelijke grondslag vereist. In die gevallen kunnen regels uit de Awb in beginsel niet analoog worden toegepast.

\section{Bijlagen:}

Tabel Awb - Lar

\begin{tabular}{|c|c|c|c|}
\hline Awb & Lar Curaçao & $\begin{array}{l}\text { analogie (deels als } \\
\text { ongeschreven recht) }\end{array}$ & onderwerp \\
\hline I:I lid I sub a & - & - & a-bestuursorgaan \\
\hline I:I lid I sub b & 2 lid I aanhef & analoog & b-bestuursorgaan \\
\hline I:I lid 2 & 2 lid I & deels analoog & uitzonderingen bestuursorgaan \\
\hline I:I lid 2 sub f & 2 lid 2 & deels analoog & voorzitters etc. \\
\hline I:I lid 3 & - & - & ambtenarenzaken \\
\hline I:I lid 4 & - & analoog & vermogensrechtelijke gevolgen \\
\hline $\mathrm{I}: 2$ & 7 lid I & deels analoog & belanghebbende \\
\hline I:3 lid I & - & - & besluit \\
\hline I:3 lid 2 & 3 & deels analoog & beschikking \\
\hline I:3 lid 3 & - & deels analoog & aanvraag \\
\hline I:3 lid 4 & - & deels analoog & beleidsregel \\
\hline $\mathrm{I}: 4$ & I lid I & deels analoog & bestuursrechter \\
\hline I:5 lid I & 54 en 55 & analoog & bezwaar \\
\hline I:5 lid 2 & - & analoog & administratief beroep \\
\hline I:5 lid 3 & 7 lid I & deels analoog & beroep \\
\hline $\mathrm{I}: 6$ & 7 lid 2 sub i & deels analoog & afbakening met het strafrecht \\
\hline$|: 7-|: 9$ & - & - & Europese Unie \\
\hline 2: I lid I & 57 lid I & deels analoog & gemachtigde \\
\hline $2: 1$ lid 2 & 57 lid 2 & analoog & machtiging \\
\hline $2: 2$ & - & - & weigeren gemachtigde \\
\hline $2: 3$ & 20 lid 259 lid 2 & analoog & doorzendplicht \\
\hline $2: 4$ & - & analoog & onpartijdigheid bestuursorgaan \\
\hline $2: 5$ & - & - & geheimhoudingsplicht \\
\hline $2: 6$ & - & - & taal \\
\hline $2: 13-2: 17$ & - & analoog & elektronisch verkeer met bestuur \\
\hline $3: 1$ & - & deels analoog & bereik Awb \\
\hline $3: 2$ & - & analoog & formele zorgvuldigheid \\
\hline $3: 3$ & - & analoog & verbod van détournement de pouvoir \\
\hline 3:4 lid I & - & analoog & gebod van belangenafweging \\
\hline
\end{tabular}




\begin{tabular}{|c|c|c|c|}
\hline Awb & Lar Curaçao & $\begin{array}{l}\text { analogie (deels als } \\
\text { ongeschreven recht) }\end{array}$ & onderwerp \\
\hline $3: 4$ lid 2 & - & analoog & materiële zorgvuldigheid \\
\hline $3: 5-3: 9 a$ & - & - & advisering \\
\hline $3: 10-3: 18$ & - & - & $\begin{array}{l}\text { uniforme openbare voorbereidings- } \\
\text { procedure }\end{array}$ \\
\hline $3: 19-3: 29$ & - & - & samenhangende besluiten \\
\hline 3:40 & - & analoog & inwerkingtreding \\
\hline 3:4I lid I & 16 lid 56 lid 2 & analoog & bekendmaking \\
\hline $3: 4$ I lid 2 & - & - & bekendmaking op een andere wijze \\
\hline $3: 42$ & - & - & publicatie besluiten \\
\hline $3: 43$ & - & - & mededelingsplicht \\
\hline $3: 44$ & - & - & $\begin{array}{l}\text { mededeling na uniforme openbare } \\
\text { voorbereidingsprocedure }\end{array}$ \\
\hline $3: 45$ & 16 lid 556 lid 5 & analoog & rechtsmiddelenverwijzing \\
\hline 3:46 & - & analoog & motiveringsplicht \\
\hline $3: 47$ & - & analoog & bekendmaking motivering \\
\hline $3: 48$ & - & analoog & achterwege laten motivering \\
\hline $3: 49$ & - & - & verwijzen naar advies \\
\hline $3: 50$ & - & analoog & afwijken van advies \\
\hline $4: 1-4: 5$ & - & - & aanvraag van een beschikking \\
\hline $4: 6$ & - & analoog & herhaalde aanvraag \\
\hline $4: 7-4: 12$ & - & deels analoog & horen van de aanvrager \\
\hline $4: 13-4: 15$ & - & - & beslistermijn beschikking \\
\hline $4: 16-4: 20$ & - & - & dwangsom bij niet tijdig beslissen \\
\hline $4: 20 a-4: 20 f$ & - & - & positieve fictieve beschikking \\
\hline $4: 21-4: 80$ & - & - & subsidie \\
\hline $4: 81-4: 84$ & - & analoog & beleidsregels \\
\hline $4: 85-4: 125$ & - & - & bestuurlijke geldschulden \\
\hline 5: I lid I & - & analoog & overtreding \\
\hline 5:I lid I en 2 & - & analoog & overtreders \\
\hline 5:2 lid I sub a & - & analoog & bestuurlijke sanctie \\
\hline $5: 2$ lid I sub b & - & analoog & herstelsanctie \\
\hline $5: 2$ lid I sub c & - & analoog & bestraffende sanctie \\
\hline $5: 2$ lid 2 & - & analoog & geen bestuurlijke sanctie \\
\hline $5: 3$ & - & analoog & analoge toepassing \\
\hline $5: 4$ & - & analoog & legaliteitsbeginsel \\
\hline $5: 5$ & - & analoog & rechtvaardigingsgrond \\
\hline $5: 6$ & - & - & cumulatie herstelsancties \\
\hline $5: 7$ & - & analoog & preventieve herstelsanctie \\
\hline
\end{tabular}




\section{(Vervolg)}

\begin{tabular}{|c|c|c|c|}
\hline Awb & Lar Curaçao & $\begin{array}{l}\text { analogie (deels als } \\
\text { ongeschreven recht) }\end{array}$ & onderwerp \\
\hline $5: 8$ & - & analoog & meer overtredingen \\
\hline $5: 9$ & - & - & inhoud sanctiebeschikking \\
\hline 5:10 lid I & - & analoog & bestemming geldelijke sanctie \\
\hline 5:10 lid 2 & - & - & invordering geldelijke sanctie \\
\hline $5: 10 a$ & - & - & cautie \\
\hline $5: 11$ & - & analoog & toezicht \\
\hline $5: 12$ & - & - & legitimatiebewijs \\
\hline $5: 13$ & - & analoog & proportionaliteit \\
\hline $5: 14$ & - & analoog & beperking bevoegdheden \\
\hline $5: 15$ & - & - & betreden plaatsen \\
\hline $5: 16$ & - & - & inlichtingen vorderen \\
\hline $5: 16 a$ & - & - & vorderen identiteitsbewijs \\
\hline $5: 17$ & - & - & inzage zakelijke gegevens \\
\hline $5: 18$ & - & - & monsterneming \\
\hline $5: 19$ & - & - & onderzoek vervoermiddelen \\
\hline $5: 20$ & - & - & verplichting tot medewerking \\
\hline $5: 21$ & - & analoog & last onder bestuursdwang \\
\hline $5: 23$ & - & - & openbare orde \\
\hline $5: 24$ & - & deels analoog & inhoud beschikking \\
\hline $5: 25$ & - & - & kostenverhaal \\
\hline $5: 27$ & - & - & betreden plaatsen \\
\hline $5: 28$ & - & - & verzegelen \\
\hline $5: 29$ & - & - & meevoeren en opslaan \\
\hline $5: 30$ & - & - & verkoop of vernietiging \\
\hline $5: 31$ & - & - & spoedeisende situatie \\
\hline $5: 31 \mathrm{a}$ & - & - & verzoek tot toepassing \\
\hline $5: 3 \mathrm{lb}$ & - & - & vervallen beschikking \\
\hline $5: 3$ lc & - & - & bezwaar en beroep \\
\hline $5: 31 d$ & - & analoog & last onder dwangsom \\
\hline $5: 32$ & - & - & als alternatieve sanctie \\
\hline $5: 32 a$ & - & - & herstelmaatregelen \\
\hline $5: 32 b$ & - & - & bedrag \\
\hline $5: 33$ & - & - & termijn verbeurde dwangsommen \\
\hline $5: 34$ & - & - & opheffing/opschorting \\
\hline $5: 35$ & - & - & verjaring invordering \\
\hline $5: 37$ & - & - & beschikking invordering \\
\hline $5: 38$ & - & - & verval beschikking \\
\hline
\end{tabular}




\begin{tabular}{|c|c|c|c|}
\hline Awb & Lar Curaçao & $\begin{array}{l}\text { analogie (deels als } \\
\text { ongeschreven recht) }\end{array}$ & onderwerp \\
\hline $5: 39$ & - & - & bezwaar/beroep \\
\hline $5: 40$ & - & analoog & boete \\
\hline $5: 41$ & - & analoog & verwijtbaarheid \\
\hline $5: 42$ & - & analoog & overlijden overtreder \\
\hline $5: 43$ & - & analoog & ne bis in idem \\
\hline $5: 44$ & - & analoog & una via \\
\hline $5: 45$ & - & - & verval bevoegdheid \\
\hline $5: 46$ & - & analoog & hoogte boete \\
\hline $5: 47$ & - & - & verval boete \\
\hline $5: 48$ & - & - & rapport \\
\hline $5: 49$ & - & - & inzagerecht \\
\hline $5: 50$ & - & - & zienswijze \\
\hline $5: 51$ & - & - & beslistermijn \\
\hline $5: 52$ & - & analoog & inhoud beschikking \\
\hline $5: 53$ & - & - & verplicht rapport \\
\hline $5: 54$ & - & - & schakelbepaling \\
\hline $6: 1$ & - & - & $\begin{array}{l}\text { toepassingsbereik bezwaar en } \\
\text { beroep }\end{array}$ \\
\hline $6: 2$ & 3 lid 2 en 3 & deels analoog & weigering en te late beslissing \\
\hline $6: 3$ & 7 lid 2 sub e & analoog & voorbereidingshandeling \\
\hline $6: 4$ & I5 lid I / 55 & analoog & bezwaar en beroep \\
\hline $6: 5$ lid I en 2 & I 5 lid 5 / 57 lid 4 & deels analoog & inhoud bezwaar-/beroepschrift \\
\hline $6: 5$ lid 3 & - & - & vertaling bezwaar-/beroepschrift \\
\hline $6: 6$ & $22 / 60$ & analoog & herstel verzuim \\
\hline $6: 7$ & 16 lid I / 56 lid I & analoog & termijn bezwaar/beroep \\
\hline $6: 8$ lid I & I 6 lid I /56 lid I & analoog & aanvang termijn \\
\hline $6: 8$ lid 2-4 & - & - & aanvang termijn bijzonderheden \\
\hline $6: 9$ lid I & - & analoog & ontvangst \\
\hline $6: 9$ lid 2 & - & - & per post ingediend \\
\hline $6: 10$ & $16 \operatorname{lid} 3 / 56 \operatorname{lid} 3$ & analoog & prematuur bezwaar/beroep \\
\hline $6: 11$ & $16 \operatorname{lid} 4 / 56 \operatorname{lid} 4$ & analoog & $\begin{array}{l}\text { verschoonbare termijnoverschrij- } \\
\text { ding }\end{array}$ \\
\hline $6: 12$ & $16 a / 56 a$ & deels analoog & $\begin{array}{l}\text { beroepstermijn bij fictieve weige- } \\
\text { ring }\end{array}$ \\
\hline $6: 13$ & - & deels analoog & $\begin{array}{l}\text { geen beroep bij geen inspraak/over- } \\
\text { slaan bezwaar }\end{array}$ \\
\hline $6: 14$ & $\begin{array}{l}20 \text { lid I / } 23 \text { lid I / } \\
59 \text { lid I }\end{array}$ & analoog & ontvangstbevestiging/kennisgeving \\
\hline
\end{tabular}




\section{(Vervolg)}

\begin{tabular}{|c|c|c|c|}
\hline Awb & Lar Curaçao & $\begin{array}{l}\text { analogie (deels als } \\
\text { ongeschreven recht) }\end{array}$ & onderwerp \\
\hline $6: 15$ & 20 lid $2 / 59$ lid 2 & analoog & doorzendplicht \\
\hline $6: 16$ & - & analoog & geen schorsende werking \\
\hline $6: 17$ & - & analoog & stukken naar gemachtigde \\
\hline $6: 19$ lid I-2 en 4-6 & $9 b / 69 a$ & analoog & $\begin{array}{l}\text { intrekking of wijziging hangende } \\
\text { beroep }\end{array}$ \\
\hline $6: 19$ lid 3 & $9 a$ lid 2 & analoog & mededeling \\
\hline $6: 20$ & $9 c / 69 b$ & deels analoog & alsnog beslissing \\
\hline $6: 21$ lid I & - & analoog & schriftelijk intrekken \\
\hline $6: 21$ lid 2 & - & analoog & mondeling intrekken \\
\hline $6: 22$ & $50 a / 68$ lid 3 & analoog & passeren gebreken \\
\hline $6: 23$ & $16 \operatorname{lid} 5 / 56 \operatorname{lid} 5$ & analoog & rechtsmiddelverwijzing \\
\hline $6: 24$ & 77 & deels analoog & schakelbepaling hoger beroep \\
\hline $7: 1$ & - & - & verplicht bezwaar \\
\hline $7: 1 \mathrm{a}$ & - & - & overslaan bezwaar \\
\hline $7: 2$ & 64 lid I en 2 & deels analoog & horen \\
\hline $7: 3$ & 67 & deels analoog & afzien horen \\
\hline 7:4 lid I & 61 lid 3 / 64 lid 5 & - & nadere stukken \\
\hline 7:4 lid 2-8 & 63 & - & terinzagelegging \\
\hline $7: 5$ & $64 \operatorname{lid} 6$ & deels analoog & hoorder/besloten horen \\
\hline $7: 6$ & 64 lid I & deels analoog & tegelijk of afzonderlijk horen \\
\hline $7: 7$ & 66 & analoog & verslag hoorzitting \\
\hline $7: 8$ & 65 lid I & deels analoog & getuigen en deskundigen \\
\hline $7: 9$ & - & - & nieuwe feiten en omstandigheden \\
\hline $7: 10$ & - & - & beslistermijn \\
\hline $7: 11$ & 68 lid I & analoog & heroverweging \\
\hline $7: 12$ & 68 lid 2 / 69 lid 2 & deels analoog & motivering en bekendmaking \\
\hline $7: 13$ lid I & 71 & - & samenstelling adviescommissie \\
\hline $7: 13$ lid 2 en 6 & 74 lid I & - & advies en verslag \\
\hline $7: 13$ lid 3 & 70 lid I & - & adviescommissie \\
\hline $7: 13$ lid 4 & 73 & - & bevoegdheden commissie \\
\hline $7: 13$ lid 5 & - & - & vertegenwoordiger bestuursorgaan \\
\hline $7: 13$ lid 6 & 70 lid 3 en 4 & analoog & afwijking van advies/bekendmaking \\
\hline $7: 14-7: 14 a$ & - & - & schakelbepalingen \\
\hline $7: 15$ & 58 & deels analoog & kosten \\
\hline $7: 16-7: 28$ & - & - & administratief beroep \\
\hline 8:1 & 7 lid I & deels analoog & beroep \\
\hline $8: 2$ & 3 lid 2 en 3 & - & gelijkgestelde besluiten \\
\hline
\end{tabular}




\begin{tabular}{|c|c|c|c|}
\hline Awb & Lar Curaçao & $\begin{array}{l}\text { analogie (deels als } \\
\text { ongeschreven recht) }\end{array}$ & onderwerp \\
\hline $8: 3-8: 5$ & 7 lid 2 & deels analoog & uitgezonderde besluiten \\
\hline $8: 6$ & 7 lid I / I I lid I & - & absolute competentie \\
\hline $8: 7$ & 10 & - & relatieve competentie \\
\hline $8: 8$ & - & - & meer dan één bevoegde rechtbank \\
\hline $8: 9$ & - & - & competentieconflicten \\
\hline 8:10-8:।1 & I I lid 2 & - & meervoudige kamer \\
\hline $8: 12$ & 30 lid 2 & analoog & rechter-commissaris \\
\hline $8: 12 a$ & - & - & conclusie \\
\hline $8: 13$ & $10 \operatorname{lid} 2$ & - & verwijzing \\
\hline $8: 14$ & 21 & analoog & voeging en splitsing \\
\hline 8:15-8:20 & 34 & analoog & wraking en verschoning \\
\hline $8: 21$ & - & analoog & $\begin{array}{l}\text { vertegenwoordiging van handelings- } \\
\text { onbekwamen }\end{array}$ \\
\hline $8: 22$ & - & - & $\begin{array}{l}\text { faillissement, surseance en schuld- } \\
\text { sanering }\end{array}$ \\
\hline $8: 23$ & 37 lid 2 & - & vertegenwoordiging bestuursorgaan \\
\hline $8: 24$ & 15 lid 2-3 & analoog & gemachtigde \\
\hline $8: 25$ & - & - & $\begin{array}{l}\text { weigering bijstand en vertegen- } \\
\text { woordiging }\end{array}$ \\
\hline $8: 26$ & 26 lid I en 3 & analoog & derdebelanghebbende \\
\hline $8: 27$ & 33 / 39 & - & verschijningsplicht \\
\hline $8: 28$ & 29 lid I / I0I & analoog & inlichtingenplicht \\
\hline $8: 28 a$ & - & - & zwijgrecht bij boete \\
\hline $8: 29$ & 24 & deels analoog & geheimhouding \\
\hline $8: 30$ & - & - & $\begin{array}{l}\text { medewerking deskundigenonder- } \\
\text { zoek }\end{array}$ \\
\hline $8: 31$ & $39 / 101$ & - & $\begin{array}{l}\text { gevolgen niet-naleven verplichtin- } \\
\text { gen }\end{array}$ \\
\hline $8: 32$ & 32 & deels analoog & $\begin{array}{l}\text { beperkte kennisneming op medi- } \\
\text { sche gronden }\end{array}$ \\
\hline $8: 33$ lid I & 38 lid 4 / 44 lid I & analoog & $\begin{array}{l}\text { oproepen getuigen/getuigenis afleg- } \\
\text { gen }\end{array}$ \\
\hline 8:33 lid2 & 38 lid I & - & oproeping getuige \\
\hline $8: 33$ lid 3 & 39 & deels analoog & opbrengen getuige \\
\hline $8: 33$ lid 4 & 44 lid 2 & analoog & eed of belofte \\
\hline $8: 34$ lid I & 44 lid I & analoog & taakvervulling deskundigen \\
\hline $8: 34$ lid 2 & - & - & geheimhouding en verschoning \\
\hline $8: 35$ lid I & $\begin{array}{l}38 \text { lid } 4 \text { / } 39 \text { / } 44 \\
\text { lid I }\end{array}$ & deels analoog & verpliching/opbrengen tolk \\
\hline
\end{tabular}




\section{(Vervolg)}

\begin{tabular}{|c|c|c|c|}
\hline Awb & Lar Curaçao & $\begin{array}{l}\text { analogie (deels als } \\
\text { ongeschreven recht) }\end{array}$ & onderwerp \\
\hline $8: 35$ lid 2 & - & - & oproeping tolk \\
\hline 8:36 lid I & 40 lid I & deels analoog & vergoeding door Land \\
\hline $8: 36$ lid 2 & 40 lid 2 & analoog & vergoeding door partij \\
\hline $8: 37$ & - & deels analoog & verzending van stukken \\
\hline $8: 38$ & - & - & terugontvangst verzending \\
\hline 8:39 lid I & $\begin{array}{l}23 \text { lid I / } 25 \text { / } 26 \\
\text { lid I }\end{array}$ & deels analoog & verzenden stukken door griffier \\
\hline $8: 39$ lid 2 & - & - & ter inzage leggen stukken \\
\hline $8: 39$ lid 3 & 31 lid 2 en 3 & analoog & afschriften en uittreksels \\
\hline $8: 40$ & - & - & $\begin{array}{l}\text { toezending bij gezamenlijk beroep- } \\
\text { schrift }\end{array}$ \\
\hline $8: 40 a$ & - & analoog & $\begin{array}{l}\text { elektronisch verkeer met bestuurs- } \\
\text { rechter }\end{array}$ \\
\hline $8: 41$ & 17 & deels analoog & griffierecht \\
\hline $8: 41 \mathrm{a}$ & - & analoog & finaliteit \\
\hline $8: 42$ & $23 / 28$ & deels analoog & $\begin{array}{l}\text { verweerschrift en stukken van } \\
\text { bestuur }\end{array}$ \\
\hline $8: 43$ & 27 & deels analoog & repliek en dupliek \\
\hline $8: 44$ & 30 lid 3 sub $f$ & deels analoog & comparitie \\
\hline 8:45 lid I-3 & $\begin{array}{l}28 \text { lid I / } 29 \text { lid I / } \\
30 \text { lid } 3 \text { sub e }\end{array}$ & deels analoog & $\begin{array}{l}\text { inwinnen ambtsberichten/ inlichtin- } \\
\text { gen }\end{array}$ \\
\hline 8:45 lid 4 & - & - & advies en inlichtingen bij EU \\
\hline $8: 45 a$ & - & - & opmerkingen EU \\
\hline 8:46 lid I & $\begin{array}{l}30 \text { lid } 3 \text { sub a en } \\
\text { lid } 8\end{array}$ & analoog & oproepen getuigen \\
\hline $8: 46$ lid 2 & 38 lid I & - & oproeping getuigen \\
\hline 8:46 lid 3 & 44 lid 4 & - & horen getuigen \\
\hline $8: 47$ lid I -2 en 4 & $\begin{array}{l}29 \text { lid } 2 \text { / } 30 \text { lid } 3 \\
\text { sub b }\end{array}$ & analoog & verslag en advies deskundige \\
\hline $8: 47$ lid 3, 5 en 6 & 29 lid 2 & deels analoog & inbreng partijen \\
\hline $8: 48$ & - & - & arts-deskundige \\
\hline $8: 49$ & 38 lid I & analoog & benoemen tolk \\
\hline $8: 50$ & $\begin{array}{l}30 \text { lid } 3 \text { sub c / } \\
\text { lid } 5,6 \text { en } 9\end{array}$ & deels analoog & descente \\
\hline $8: 51$ & - & - & descente door griffier \\
\hline $8: 5 \mathrm{la}-8: 85 \mathrm{Id}$ & - & - & bestuurlijke lus \\
\hline $8: 52$ lid I en 2 & 81 & deels analoog & versnelde behandeling \\
\hline $8: 52$ lid 3 en $8: 53$ & 82 & deels analoog & $\begin{array}{l}\text { behandeling en einde versnelde } \\
\text { behandeling }\end{array}$ \\
\hline $8: 54$ & 79 & deels analoog & vereenvoudigde behandeling \\
\hline
\end{tabular}




\begin{tabular}{|c|c|c|c|}
\hline Awb & Lar Curaçao & $\begin{array}{l}\text { analogie (deels als } \\
\text { ongeschreven recht) }\end{array}$ & onderwerp \\
\hline $8: 54 a$ & - & - & ten onrechte rechtstreeks beroep \\
\hline $8: 55$ & 80 & deels analoog & verzet \\
\hline $8: 55 b-8: 55 f$ & - & - & beroep bij niet tijdig handelen \\
\hline $8: 56$ & 33 & deels analoog & uitnodiging zitting \\
\hline $8: 57$ & 35 & deels analoog & achterwege blijven zitting \\
\hline $8: 58$ & 27 lid 4 & deels analoog & nadere stukken \\
\hline $8: 59$ & 37 lid I & analoog & in persoon verschijnen \\
\hline $8: 60$ & 38 & deels analoog & getuigen, deskundigen, tolken \\
\hline $8: 60 a$ & - & - & inbreng EU \\
\hline $8: 61$ & $4 I$ en 46 & deels analoog & orde en proces-verbaal zitting \\
\hline $8: 62$ & 33 lid I / 42 & deels analoog & openbaarheid zitting \\
\hline $8: 63$ & 44 & deels analoog & horen getuigen en deskundigen \\
\hline $8: 64$ & - & analoog & schorsing behandeling \\
\hline $8: 65$ lid I & 46a lid I & analoog & sluiting behandeling \\
\hline $8: 65$ lid 2 & 45 & analoog & laatste woord partijen \\
\hline $8: 65$ lid 3 & 46a lid 2 & analoog & datum uitspraak \\
\hline $8: 66$ & 49 & deels analoog & schriftelijke uitspraak \\
\hline $8: 67$ & 52 & deels analoog & mondelinge uitspraak \\
\hline $8: 68$ & 48 & analoog & heropening onderzoek \\
\hline $8: 69$ & 47 & analoog & grondslag uitspraak \\
\hline $8: 69 a$ & - & - & relativiteitsvereiste \\
\hline $8: 70$ & 50 lid I & analoog & dicta \\
\hline $8: 71$ & 50 lid 2 & analoog & burgerlijke rechter \\
\hline $8: 72$ lid I-3 sub a & 50 lid 3 & analoog & vernietiging besluit \\
\hline $\begin{array}{l}8: 72 \text { lid } 3 \text { sub b en } \\
4 \text { sub b }\end{array}$ & 50 lid 4 & analoog & nieuw besluit \\
\hline $8: 72$ lid 4 sub a & - & - & voorbereiding uitsluiten \\
\hline $8: 72$ lid 5 & 50 lid 7 & deels analoog & voorlopige voorziening \\
\hline $8: 72$ lid 6 & 50 lid 8 & analoog & dwangsom \\
\hline $8: 72 a$ & - & - & zelf opleggen boete \\
\hline 8:74 lid I & $17 \operatorname{lid} 7$ & analoog & $\begin{array}{l}\text { terugbetaling griffierecht bij } \\
\text { gegrond beroep }\end{array}$ \\
\hline $8: 74$ lid 2 & - & analoog & $\begin{array}{l}\text { terugbetaling griffierecht in andere } \\
\text { gevallen }\end{array}$ \\
\hline $8: 75$ & 50 lid 9 & deels analoog & veroordeling in proceskosten \\
\hline $8: 75 a$ & 50 lid 10 en II & analoog & proceskosten bij intrekking beroep \\
\hline $8: 76$ & 50 lid 12 & analoog & executoriale titel \\
\hline $8: 77$ & 49 & deels analoog & inhoud uitspraak \\
\hline
\end{tabular}


(Vervolg)

\begin{tabular}{|c|c|c|c|}
\hline Awb & Lar Curaçao & $\begin{array}{l}\text { analogie (deels als } \\
\text { ongeschreven recht) }\end{array}$ & onderwerp \\
\hline 8:78 & 5 I lid I & analoog & openbaarheid uitspraak \\
\hline 8:79 lid I & 51 lid 2 & deels analoog & verstrekking uitspraak \\
\hline 8:79 lid 2-3 & 53 & analoog & afschrift uitspraak \\
\hline $8: 80$ & - & - & $\begin{array}{l}\text { bekendmaking vervangende uit- } \\
\text { spraak }\end{array}$ \\
\hline $8: 80 \mathrm{a}$ & - & - & tussenuitspraak \\
\hline $8: 81$ & 85 & deels analoog & voorlopige voorziening \\
\hline $8: 82$ & $\begin{array}{l}85 \text { lid } 3 \text { tweede vol- } \\
\text { zin }\end{array}$ & deels analoog & griffierecht \\
\hline $8: 83$ & 86 en 87 & deels analoog & zitting \\
\hline $8: 84$ & 86 & deels analoog & uitspraak \\
\hline $8: 85$ & 91 & analoog & vervallen vovo \\
\hline $8: 86$ & 95 & deels analoog & kortsluiting \\
\hline $8: 87$ & 90 & deels analoog & opheffing/wijziging \\
\hline 8:88-8:95 & - & - & schadevergoeding \\
\hline $8: 104$ & 75 & deels analoog & hoger beroep \\
\hline $8: 105$ & 76 & - & bevoegde instantie \\
\hline $8: 106$ & - & - & schorsende werking \\
\hline $8: 107$ & $76 a$ & deels analoog & doorzending \\
\hline $8: 108$ & 77 & - & toepasselijk procesrecht \\
\hline $8: 109$ & 77 lid I & - & griffierecht \\
\hline 8:1 I0-8: 112 & - & - & incidenteel hoger beroep \\
\hline 8:1 I3 lid I & 78 lid I & analoog & uitspraak \\
\hline 8:1 I 3 lid 2 & - & - & hoger beroep na nieuw besluit \\
\hline 8: I I4 lid I & $78 \mathrm{e}$ & deels analoog & terugbetalen griffierecht \\
\hline 8: I I 4 lid 2 & - & - & uitzondering \\
\hline $8: 115$ & 78 lid 2 & deels analoog & terugverwijzing \\
\hline $8: 116$ & $\begin{array}{l}78 \text { lid } 2 \text { laatste bij- } \\
\text { zin }\end{array}$ & analoog & zelf afdoen \\
\hline $8: 117$ & - & - & gedekt verklaren onbevoegdheid \\
\hline $8: 118$ & 77 lid I jo. 50 lid 9 & deels analoog & veroordeling in proceskosten \\
\hline 8: I I9 lid I & 96 lid I & analoog & herziening \\
\hline 8: I I9 lid 2 & 96 lid 2 & deels analoog & procesregels herziening \\
\hline $9: 1-9: 36$ & - & - & klachtbehandeling \\
\hline $10: 1$ & - & analoog & mandaat \\
\hline $10: 2$ & - & analoog & rechtsgevolg \\
\hline I0:3 lid I & - & analoog & $\begin{array}{l}\text { onbevoegdheid tot mandaatverle- } \\
\text { ning }\end{array}$ \\
\hline
\end{tabular}




\begin{tabular}{|c|c|c|c|}
\hline Awb & Lar Curaçao & $\begin{array}{l}\text { analogie (deels als } \\
\text { ongeschreven recht) }\end{array}$ & onderwerp \\
\hline 10:3 lid 2-4 & - & - & $\begin{array}{l}\text { onbevoegdheid tot mandaatverle- } \\
\text { ning }\end{array}$ \\
\hline $10: 4$ & - & - & instemming van niet-ondergeschikte \\
\hline I0:5 lid I & - & analoog & soort mandaat \\
\hline 10:5 lid 2 & - & - & schriftelijke verlening \\
\hline $10: 6$ & - & analoog & instructiebevoegdheid \\
\hline $10: 7$ & - & analoog & mandaatgever blijft bevoegd \\
\hline $10: 8$ & - & analoog & intrekken mandaat \\
\hline I0:9 lid I & - & analoog & ondermandaat \\
\hline $10: 9$ lid 2 & - & deels analoog & $\begin{array}{l}\text { van overeenkomstige toepassing } \\
\text { regels }\end{array}$ \\
\hline $10: 10$ & - & - & vermelden mandaatgever \\
\hline $10: 11$ & - & analoog & ondertekeningsmandaat \\
\hline $10: 12$ & - & - & volmacht/machtiging \\
\hline $10: 13$ & - & analoog & delegatie \\
\hline $10: 14$ & - & - & niet aan ondergeschikten \\
\hline $10: 15$ & - & analoog & wettelijke grondslag \\
\hline $10: 16$ & - & niet analoog & beleidsregels \\
\hline $10: 17$ & - & analoog & verlies bevoegdheid \\
\hline $10: 18$ & - & analoog & intrekken bevoegdheid \\
\hline $10: 19$ & - & - & vermelden delegatiebesluit \\
\hline $10: 20$ & - & - & allodelegatie \\
\hline$|0: 2|$ & - & - & schakelbepaling \\
\hline $10: 22$ & - & analoog & attributie aan ondergeschikten \\
\hline $10: 23$ & - & analoog & schakelbepaling \\
\hline $10: 25$ & - & analoog & goedkeuring \\
\hline $10: 26$ & - & analoog & wettelijke grondslag \\
\hline $10: 27$ & - & - & onthouden goedkeuring \\
\hline $10: 28$ & - & - & uitspraak rechter \\
\hline $10: 29$ & - & - & gedeeltelijke goedkeuring \\
\hline $10: 30$ & - & - & overleg \\
\hline $10: 31$ & - & - & bekendmaking \\
\hline $10: 32$ & - & - & toestemming \\
\hline $10: 33$ & - & - & regels vernietiging \\
\hline $10: 34$ & - & analoog & wettelijke grondslag \\
\hline $10: 35$ & - & - & gronden vernietiging \\
\hline $10: 36$ & - & analoog & gedeeltelijke vernietiging \\
\hline $10: 37$ & - & - & rechterlijke uitspraak \\
\hline
\end{tabular}




\begin{tabular}{llll} 
(Vervolg) & & & \\
\hline Awb & Lar Curaçao & $\begin{array}{l}\text { analogie (deels als } \\
\text { ongeschreven recht) }\end{array}$ & onderwerp \\
\hline $10: 38$ & - & - & goedkeuring, bezwaar en beroep \\
$10: 39$ & - & - & privaatrechtelijke rechtshandeling \\
$10: 40$ & - & - & na verloop schorsing geen vernieti- \\
& - & - & ging \\
$10: 41$ & - & - & overleg \\
$10: 42$ & - & - & rechtsgevolgen \\
$10: 43$ & - & - & schorsing \\
$10: 44$ & - & - & duur \\
$10: 45$ & - & - & schakelbepaling \\
$11: 2$ & - & - & indexatie \\
$11: 3$ & - & - & overgangsrecht \\
$11: 4$ & 103 & & citeertitel \\
\hline
\end{tabular}

Tabel Lar-Awb

\begin{tabular}{|c|c|c|c|}
\hline Lar Curaçao & Awb & $\begin{array}{l}\text { analogie (deels als } \\
\text { ongeschreven recht) }\end{array}$ & onderwerp \\
\hline I lid I & $\mathrm{I}: 4$ & deels analoog & bestuursrechter \\
\hline 2 lid I aanhef & I:I lid I sub b & analoog & b-bestuursorgaan \\
\hline 2 lid $I$ & I:I lid 2 & deels analoog & uitzonderingen bestuursorgaan \\
\hline $2 \operatorname{lid} 2$ & I:I lid 2 sub $f$ & deels analoog & voorzitters etc. \\
\hline 3 lid I & $1: 3$ lid 2 en $8: 2$ & deels analoog & beschikking \\
\hline 3 lid 2 en 3 & $6: 2$ & deels analoog & weigering en te late beslissing \\
\hline 4 & - & - & einde termijn/feestdagen \\
\hline 5 & $8: 37$ & deels analoog & aangetekende brief \\
\hline 6 & - & - & kosteloze bijstand/vrij van zegel \\
\hline 7 lid I & $\mathrm{I}: 2$ & deels analoog & belanghebbende \\
\hline 7 lid I & 8:1 & - & instellen beroep \\
\hline 7 lid 2 & $8: 3-8: 5$ & deels analoog & uitgezonderde beschikkingen \\
\hline 7 lid 2 sub e & $6: 3$ & analoog & voorbereidingshandeling \\
\hline 7 lid 2 sub i & $\mathrm{I}: 6$ & deels analoog & afbakening met het strafrecht \\
\hline 8 & - & - & $\begin{array}{l}\text { beroepen sociale zekerheid en ces- } \\
\text { santia }\end{array}$ \\
\hline 9 lid I & - & - & beroepsgronden \\
\hline $9 \operatorname{lid} 2$ & $8: 77$ lid 2 & deels analoog & geschonden recht \\
\hline 9a lid I & - & - & intrekken of wijzigen \\
\hline $9 a$ lid 2 & $6: 19$ lid 3 & analoog & mededeling \\
\hline 9b lid I & $6: 19$ lid I & analoog & $\begin{array}{l}\text { beroep mede betrekking op intrek- } \\
\text { king of wijziging }\end{array}$ \\
\hline
\end{tabular}




\begin{tabular}{|c|c|c|c|}
\hline Lar Curaçao & Awb & $\begin{array}{l}\text { analogie (deels als } \\
\text { ongeschreven recht) }\end{array}$ & onderwerp \\
\hline $9 b$ lid 2 & $6: 19$ lid 2 & analoog & ook na ingesteld beroep \\
\hline $9 b$ lid 3 & $6: 19$ lid 4 & analoog & doorzenden door ander orgaan \\
\hline $9 b$ lid 4 & $6: 19$ lid 6 & analoog & vernietiging na intrekking \\
\hline $9 c$ & $6: 20$ & deels analoog & $\begin{array}{l}\text { beroep mede betrekking op alsnog } \\
\text { beslissing }\end{array}$ \\
\hline I0 lid I & $8: 7$ & - & relatieve competentie \\
\hline 10 lid 2 & $8: 13$ & - & verwijzing \\
\hline I I lid I & 8:6 lid I & - & absolute competentie \\
\hline II lid 2 & 8:10-8:11 & - & meervoudige kamer \\
\hline 12 & - & - & bijzondere rechters \\
\hline 13 & - & - & eed/belofte \\
\hline 14 & - & - & wijze van beraadslaging \\
\hline I5 lid I & $6: 4$ & analoog & indienen beroep \\
\hline 15 lid 2 & $8: 24$ lid I en 2 & analoog & gemachtigde/machtiging \\
\hline I5 lid 3 & $8: 24$ lid 3 & analoog & advocaat \\
\hline I5 lid 4 & - & - & domicilie \\
\hline I5 lid 5 & $6: 5$ & deels analoog & inhoud bezwaar-/beroepschrift \\
\hline 15 lid 6 & $6: 5$ lid 2 & deels analoog & beschikking/stukken \\
\hline I6 lid I & $6: 7$ en $6: 8$ lid I & analoog & termijn beroep \\
\hline 16 lid 2 & $3: 4$ I lid I & analoog & dag van bekendmaking \\
\hline 16 lid 3 & $6: 10$ & analoog & prematuur bezwaar/beroep \\
\hline $16 \operatorname{lid} 4$ & $6: 11$ & analoog & $\begin{array}{l}\text { verschoonbare termijnoverschrij- } \\
\text { ding }\end{array}$ \\
\hline 16 lid 5 & $6: 23$ & analoog & rechtsmiddelenverwijzing \\
\hline $16 a$ & $6: 12$ & deels analoog & termijn bij fictieve weigering \\
\hline |7 lid I & $8: 41$ & deels analoog & griffierecht \\
\hline 17 lid 2-4 & - & - & vrijstelling \\
\hline 17 lid 5 & 8:4I lid 4-6 & analoog & niet-ontvankelijk \\
\hline 17 lid 6 & $8: 41$ lid 7 en 8 & analoog & terugbetaling bij intrekking beroep \\
\hline 17 lid 7 & 8:74 lid I & analoog & $\begin{array}{l}\text { terugbetaling bij gegrondverklaring } \\
\text { beroep }\end{array}$ \\
\hline 17 lid 8 & - & - & terugbetaling bij terugverwijzing \\
\hline 18 & - & - & register griffier \\
\hline 19 & - & - & inlichtingenplicht griffier \\
\hline 20 lid I & $6: 14$ & analoog & ontvangstbevestiging/kennisgeving \\
\hline 20 lid 2 & $6: 15$ & analoog & doorzendplicht \\
\hline 21 & 8:14 lid I & analoog & voeging en splitsing \\
\hline 22 lid I & $6: 6$ & analoog & herstel verzuim \\
\hline
\end{tabular}


(Vervolg)

\begin{tabular}{|c|c|c|c|}
\hline Lar Curaçao & Awb & $\begin{array}{l}\text { analogie (deels als } \\
\text { ongeschreven recht) }\end{array}$ & onderwerp \\
\hline 22 lid 2 & $6: 6$ & analoog & niet-ontvankelijkheid \\
\hline 23 & $8: 42$ & deels analoog & verweerschrift \\
\hline 23 lid I & $\begin{array}{l}\text { 8:39 lid I / 8:42 } \\
\text { lid I }\end{array}$ & deels analoog & $\begin{array}{l}\text { verzenden beroepschrift/overleggen } \\
\text { stukken door bestuur }\end{array}$ \\
\hline 23 lid 2 & - & - & dwangsom \\
\hline 23 lid 3 & 8:42 lid I & deels analoog & termijn verweerschrift \\
\hline 24 lid I & 8:29 lid I & deels analoog & $\begin{array}{l}\text { geheimhouding/beperkte kennis- } \\
\text { name }\end{array}$ \\
\hline 24 lid 2 & $8: 29$ lid 2 & analoog & gewichtige redenen \\
\hline 24 lid 3 & $8: 29$ lid 3 & analoog & beslissing Gerecht \\
\hline 24 lid 4 & $8: 29$ lid 4 & analoog & verplichting vervalt \\
\hline $24 \operatorname{lid} 5$ & $8: 29$ lid 5 & analoog & $\begin{array}{l}\text { gevolgen bij gerechtvaardigde } \\
\text { beperking }\end{array}$ \\
\hline 25 & 8:39 lid I & analoog & $\begin{array}{l}\text { toezenden verweerschrift aan } \\
\text { indiener beroepschrift }\end{array}$ \\
\hline 26 lid I en 3 & $8: 26$ & analoog & $\begin{array}{l}\text { derdebelanghebbende/toezenden } \\
\text { stukken }\end{array}$ \\
\hline $26 \operatorname{lid} 3$ & $8: 26$ lid 2 & analoog & aankondiging in de pers \\
\hline 26 lid 4 & $8: 43$ lid 2 & deels analoog & schrifturen derde \\
\hline 26 lid 5 & 8:39 lid I & analoog & $\begin{array}{l}\text { zenden schrifturen naar andere par- } \\
\text { tijen }\end{array}$ \\
\hline 27 lid I & $8: 43$ lid I & analoog & repliek en dupliek \\
\hline 27 lid 2 & - & - & verlengen/verkorten termijn \\
\hline 27 lid 3 & $\begin{array}{l}\text { 8:39 lid I / 8:43 } \\
\text { lid } 2\end{array}$ & analoog & toezenden/reactie partijen \\
\hline 27 lid 4 & $8: 58$ & deels analoog & termijn indienen nadere stukken \\
\hline 28 lid I & $8: 45$ lid I & deels analoog & ambtsberichten \\
\hline 28 lid 2 & $8: 45$ lid 2 & deels analoog & verplichting \\
\hline 28 lid 3 & $8: 45$ lid I & analoog & termijn \\
\hline 28 lid 4 & $8: 45$ lid 3 & deels analoog & dwangsom en geheimhouding \\
\hline 29 lid I & 8:28 / 8:45 lid 3 & analoog & inlichtingenplicht \\
\hline 29 lid 2 & $8: 47$ & analoog & $\begin{array}{l}\text { verslag en advies deskundige/ } \\
\text { inbreng partijen }\end{array}$ \\
\hline 29 lid 3 & $8: 29$ & analoog & geheimhouding \\
\hline 30 lid I & & analoog & voorbereidend onderzoek gelasten \\
\hline 30 lid 2 & $8: 12$ & deels analoog & $\begin{array}{l}\text { door (plv.) lid Hof of rechter-com- } \\
\text { missaris }\end{array}$ \\
\hline $\begin{array}{l}30 \text { lid } 3 \text { sub a en } \\
\text { lid } 8\end{array}$ & $8: 46$ lid I & analoog & oproepen getuigen \\
\hline
\end{tabular}




\begin{tabular}{|c|c|c|c|}
\hline Lar Curaçao & Awb & $\begin{array}{l}\text { analogie (deels als } \\
\text { ongeschreven recht) }\end{array}$ & onderwerp \\
\hline $\begin{array}{l}30 \text { lid } 3 \text { sub c / lid } \\
5,6 \text { en } 9\end{array}$ & $8: 50$ & deels analoog & descente \\
\hline 30 lid 3 sub $f$ & $8: 44$ & deels analoog & comparitie \\
\hline 30 lid 4 & 8:50 lid 4 & & proces-verbaal van binnentreden \\
\hline 30 lid 5 & $\begin{array}{l}\text { 8:47 lid } 3 \text { / 8:50 } \\
\text { lid } 3\end{array}$ & deels analoog & $\begin{array}{l}\text { kennisgeving voorgenomen onder- } \\
\text { zoek }\end{array}$ \\
\hline 30 lid 6 & - & - & ordehandhaving \\
\hline 30 lid 7 & $\begin{array}{l}\text { 8:50 lid } 4 \text { / 8:5 I } \\
\text { lid } 3\end{array}$ & deels analoog & proces-verbaal \\
\hline 30 lid 8 & - & - & bijstand griffier \\
\hline $30 \operatorname{lid} 9$ & $\begin{array}{l}\text { 8:50 lid } 2 \text { / 8:5 I } \\
\text { lid } 2\end{array}$ & deels analoog & medewerking \\
\hline 30 lid 10 & 8:46 / 8:47 / 8:49 & analoog & getuigen, deskundigen, tolken \\
\hline 31 lid I & $8: 39$ lid 2 & deels analoog & terinzagelegging \\
\hline 31 lid 2 & $8: 39$ lid 3 & analoog & afschriften en uittreksels \\
\hline 31 lid 3 & $8: 39$ lid 3 & deels analoog & kosten \\
\hline 32 & $8: 32$ & analoog & $\begin{array}{l}\text { beperkte kennisname op medische } \\
\text { gronden }\end{array}$ \\
\hline 33 lid I & $8: 56$ / 8:62 & deels analoog & uitnodiging openbare zitting \\
\hline 33 lid 2 & $8: 56$ & analoog & plaats en tijdstip zitting \\
\hline 34 lid I & $8: 15$ & deels analoog & wraking \\
\hline 34 lid 2 & $8: 17$ & analoog & berusten \\
\hline 34 lid 3 & $8: 18$ & - & Hof \\
\hline 34 lid 4 & - & - & andere rechter \\
\hline 35 & $8: 57$ & deels analoog & achterwege blijven openbare zitting \\
\hline 36 & $8: 24$ & analoog & machtiging/advocaat \\
\hline 37 lid I & $8: 59$ & deels analoog & in persoon verschijnen \\
\hline 37 lid 2 & $8: 23$ & - & vertegenwoordiging bestuursorgaan \\
\hline 38 lid I & 8:60 / 8:33 lid 2 & analoog & $\begin{array}{l}\text { getuigen, deskundigen, tolken } \\
\text { oproepen }\end{array}$ \\
\hline 38 lid 2 & $8: 60$ lid 3 & analoog & namen etc. meedelen \\
\hline 38 lid 3 & $8: 60$ lid 4 & deels analoog & $\begin{array}{l}\text { meebrengen getuigen en deskundi- } \\
\text { gen }\end{array}$ \\
\hline 38 lid 4 & $8: 60$ lid 2 & analoog & verplicht gevolg geven aan oproep \\
\hline 39 & $8: 60$ lid 2 & deels analoog & opbrengen getuige, deskundige, tolk \\
\hline 40 lid I & 8:36 lid I & deels analoog & vergoeding door Land \\
\hline 40 lid 2 & - & - & geen vergoeding landsdienaren \\
\hline 40 lid 3 & $8: 36$ lid 2 & analoog & vergoeding door partij \\
\hline $40 \operatorname{lid} 4$ & $8: 76$ & analoog & executoriale titel \\
\hline
\end{tabular}


(Vervolg)

\begin{tabular}{|c|c|c|c|}
\hline Lar Curaçao & Awb & $\begin{array}{l}\text { analogie (deels als } \\
\text { ongeschreven recht) }\end{array}$ & onderwerp \\
\hline 41 & $8: 61$ lid I & analoog & orde ter zitting \\
\hline 42 & 8:62 lid I & deels analoog & gesloten deuren \\
\hline 44 lid I & $\begin{array}{l}\text { 8:33 lid I / 8:34 } \\
\text { lid I / 8:35 / 8:46 } \\
\text { lid } 3\end{array}$ & analoog & $\begin{array}{l}\text { taakvervulling getuigen, deskundi- } \\
\text { gen en tolken }\end{array}$ \\
\hline 44 lid 2 & $8: 33$ lid 4 & analoog & eed of belofte getuigen \\
\hline 44 lid 3 & - & - & formule eed/belofte \\
\hline 44 lid 4 & $8: 63$ lid I & analoog & horen getuigen/deskundigen \\
\hline 44 lid 5 & - & - & $\begin{array}{l}\text { horen niet-aangemelde getuigen/ } \\
\text { deskundigen }\end{array}$ \\
\hline 44 lid 6 & $8: 61$ & - & volgorde horen \\
\hline 44 lid 7 & $8: 61$ & - & $\begin{array}{l}\text { zich verwijderen getuigen/deskundi- } \\
\text { gen en tolken }\end{array}$ \\
\hline 45 & $8: 65$ lid 2 & analoog & laatste woord partijen \\
\hline 46 lid I & $8: 61$ lid 2 en 3 & - & proces-verbaal zitting \\
\hline 46 lid 2 & $8: 6 I$ lid 4 & analoog & inhoud proces-verbaal \\
\hline 46 lid 3 & $8: 61$ lid 5 & analoog & verdere inhoud \\
\hline 46 lid 4 & $8: 61$ lid 6 & analoog & ondertekening proces-verbaal \\
\hline 46 lid 5 & $8: 61$ lid 8 & analoog & $\begin{array}{l}\text { opnemen gehele verklaring partij/ } \\
\text { getuige/deskundige }\end{array}$ \\
\hline 46 lid 6 & - & - & geen griffier \\
\hline 46a lid I & $8: 65$ lid I & analoog & sluiting behandeling \\
\hline $46 a$ lid 2 & $8: 65$ lid 3 & analoog & mededeling datum uitspraak \\
\hline 47 & $8: 69$ & analoog & grondslag uitspraak \\
\hline 48 lid I & $8: 68$ lid I & analoog & heropening onderzoek \\
\hline 48 lid 2 & $8: 68$ lid 2 & analoog & mededeling aan partijen \\
\hline 49 lid I & $\begin{array}{l}\text { 8:66 lid I / 8:77 } \\
\text { lid I sub b }\end{array}$ & analoog & schriftelijke uitspraak/gronden \\
\hline 49 lid 2 & $8: 77$ lid I sub d & analoog & namen rechters \\
\hline 49 lid 3 & 8:77 lid 3 & deels analoog & ondertekening \\
\hline 50 lid I & $8: 70$ & analoog & dicta \\
\hline 50 lid 2 & $8: 71$ & analoog & burgerlijke rechter \\
\hline 50 lid 3 & $8: 72$ lid I -3 sub a & analoog & vernietiging besluit \\
\hline 50 lid 4 & $\begin{array}{l}8: 72 \text { lid } 3 \text { sub b en } \\
4 \text { sub b }\end{array}$ & analoog & nieuw besluit \\
\hline 50 lid 5 & - & - & schadevergoeding \\
\hline 50 lid 6 & - & - & schadestaatprocedure \\
\hline $50 \operatorname{lid} 7$ & $8: 72$ lid 5 & deels analoog & voorlopige voorziening \\
\hline 50 lid 8 & $8: 72$ lid 6 & analoog & dwangsom \\
\hline
\end{tabular}




\begin{tabular}{|c|c|c|c|}
\hline Lar Curaçao & Awb & $\begin{array}{l}\text { analogie (deels als } \\
\text { ongeschreven recht) }\end{array}$ & onderwerp \\
\hline 50 lid 9 & $8: 75$ lid I & deels analoog & veroordeling in proceskosten \\
\hline 50 lid 10 en II & $8: 75 a$ & analoog & proceskosten bij intrekking beroep \\
\hline 50 lid 12 & $8: 76$ & analoog & executoriale titel \\
\hline 50 lid I 3 & $6: 23$ jo. $6: 24$ & analoog & rechtsmiddelverwijzing \\
\hline $50 \mathrm{a}$ & $6: 22$ & analoog & passeren gebreken \\
\hline 5I lid I & $8: 78$ & analoog & openbaarheid uitspraak \\
\hline 51 lid 2 & 8:79 lid I & deels analoog & verstrekking uitspraak \\
\hline 52 lid I & $8: 67$ lid I en 2 & deels analoog & mondelinge uitspraak \\
\hline 52 lid 2 & $8: 67$ lid 3 en 4 & deels analoog & proces-verbaal/ondertekening \\
\hline 52 lid 3 & $8: 79$ lid I & deels analoog & verstrekking uitspraak \\
\hline 53 & $8: 79$ lid 2 & analoog & afschrift uitspraak \\
\hline 54 lid I & $8: 54 a$ & deels analoog & bezwaar op verzoek van Gerecht \\
\hline 54 lid 2 & - & - & terug naar Gerecht \\
\hline 54 lid 3 & - & - & als bezwaarschrift \\
\hline 54 lid 4 & - & - & kennisgeving aan indiener \\
\hline 55 & $7: 1$ & deels analoog & bezwaar door bezwaarde \\
\hline 56 lid I & $6: 7$ & analoog & bezwaartermijn zes weken \\
\hline 56 lid 2 & 3:4 I lid I & analoog & bekendmaking beschikking \\
\hline 56 lid 3 & $6: 10$ & analoog & prematuur bezwaar \\
\hline 56 lid 4 & $6: 11$ & analoog & $\begin{array}{l}\text { verschoonbare termijnoverschrij- } \\
\text { ding }\end{array}$ \\
\hline 56 lid 5 & $3: 45$ & analoog & rechtsmiddelenverwijzing \\
\hline 57 lid I & 2:I lid I & analoog & gemachtigde/domicilie \\
\hline 57 lid 2 & 2:I lid 2 & deels analoog & machtiging/advocaat \\
\hline 57 lid 3 & - & - & domicilie \\
\hline 57 lid 4 & $6: 5$ lid I & deels analoog & inhoud bezwaarschrift \\
\hline 57 lid 5 & - & - & kopie beschikking \\
\hline 58 lid I & $7: 15$ lid I & analoog & geen rechten \\
\hline 58 lid 2-4 & $7: 15$ lid 2-4 & deels analoog & kostenvergoeding \\
\hline 59 lid I & $6: 14$ lid I & analoog & ontvangstbevestiging \\
\hline 59 lid 2 & $6: 15$ lid 2 & analoog & doorzendplicht \\
\hline 60 lid I & $6: 6$ sub $a$ en $b$ & analoog & herstel verzuim \\
\hline 60 lid 2 & $6: 6$ laatste volzin & analoog & niet-ontvankelijkheid \\
\hline $6 \mathrm{I}$ lid I & $7: 2$ lid 2 & deels analoog & informeren medebelanghebbenden \\
\hline 61 lid 2 & - & - & oproepen derden \\
\hline 61 lid 3 & 7:4 lid I & deels analoog & indienen stukken \\
\hline 61 lid 4 & - & - & overschrijding termijn \\
\hline
\end{tabular}




\begin{tabular}{|c|c|c|c|}
\hline Lar Curaçao & Awb & $\begin{array}{l}\text { analogie (deels als } \\
\text { ongeschreven recht) }\end{array}$ & onderwerp \\
\hline 62 & - & - & $\begin{array}{l}\text { commentaar overheidsafdeling of } \\
\text {-dienst }\end{array}$ \\
\hline 63 lid I & $7: 4$ lid 2, 3 en 8 & deels analoog & terinzagelegging/geheimhouding \\
\hline 63 lid 2 & $7: 4$ lid 4 & analoog & afschriften \\
\hline 64 lid I & $\begin{array}{l}\text { 7:2 lid I en } 2 \text { en } 7: 6 \\
\text { lid I }\end{array}$ & deels analoog & $\begin{array}{l}\text { uitnodiging hoorzitting/tegelijk } \\
\text { horen }\end{array}$ \\
\hline 64 lid 2 & $2: 1$ & deels analoog & gemachtigde/advocaat \\
\hline 64 lid 3 & - & - & $\begin{array}{l}\text { vertegenwoordiger afdeling of } \\
\text { dienst }\end{array}$ \\
\hline 64 lid 4 & - & - & woord voeren \\
\hline 64 lid 5 & $7: 4$ lid I & - & geen stukken indienen ter zitting \\
\hline 64 lid 6 & $7: 5$ lid 2 & deels analoog & hoorder/besloten horen \\
\hline 65 lid I & $7: 8$ lid I & deels analoog & horen getuigen en deskundigen \\
\hline 65 lid 2 & - & - & $\begin{array}{l}\text { vergoeding kosten getuigen deskun- } \\
\text { digen en tolken }\end{array}$ \\
\hline 66 & $7: 7$ & analoog & verslag hoorzitting \\
\hline 67 & $7: 3$ & deels analoog & afzien horen \\
\hline 68 lid I & 7:I I lid I & analoog & heroverweging \\
\hline 68 lid 2 & $\begin{array}{l}\text { 7: I I lid } 2 \text { / 7:12 } \\
\text { lid I }\end{array}$ & deels analoog & $\begin{array}{l}\text { gronden /in plaats van besluit in } \\
\text { primo }\end{array}$ \\
\hline 68 lid 3 & $6: 22$ & analoog & passeren gebreken \\
\hline 69 lid I & $7: 10$ lid I en 3 & deels analoog & beslistermijn \\
\hline 69 lid 2 & $7: 12$ lid 2-3 & deels analoog & bekendmaking \\
\hline 69 lid 3 & $7: 12$ lid 4 & analoog & rechtsmiddelverwijzing \\
\hline 69a lid I & - & analoog & intrekken/wijzigen besluit in primo \\
\hline $69 \mathrm{a}$ lid 2 & $6: 19$ lid I & analoog & $\begin{array}{l}\text { bezwaar mede betrekking op } \\
\text { intrekking of wijziging }\end{array}$ \\
\hline $69 a$ lid 3 & $6: 19$ lid 2 & analoog & ook na bezwaarschrift \\
\hline 69a lid 4 & $6: 19$ lid 6 & analoog & vernietiging na intrekking \\
\hline 69b lid I & $\begin{array}{l}6: 19 \text { lid } 1-2 \text { en } 6: 20 \\
\text { lid } 3\end{array}$ & & $\begin{array}{l}\text { bezwaar mede betrekking op alsnog } \\
\text { besluit in primo }\end{array}$ \\
\hline 69b lid 2 & $6: 19$ lid 6 & analoog & vernietiging na alsnog beschikking \\
\hline 70 lid I & $7: 13$ lid I & deels analoog & adviescommissie \\
\hline 70 lid 2 & $4: 49$ & analoog & verwijzen naar advies \\
\hline 70 lid 3 & $7: 13$ lid 7 & analoog & afwijking van advies \\
\hline 70 lid 4 & $7: 13$ lid 7 & analoog & toezenden advies bij afwijking \\
\hline 7I lid I & $7: 13$ lid I sub a & analoog & samenstelling adviescommissie \\
\hline 7I lid 2 & $7: 13$ lid I sub b & analoog & onafhankelijkheid leden \\
\hline 7I lid 3 & - & - & secretaris \\
\hline
\end{tabular}




\begin{tabular}{|c|c|c|c|}
\hline Lar Curaçao & Awb & $\begin{array}{l}\text { analogie (deels als } \\
\text { ongeschreven recht) }\end{array}$ & onderwerp \\
\hline 72 & - & - & faciliteiten \\
\hline 73 & $7: 13$ lid 4 & deels analoog & $\begin{array}{l}\text { bevoegdheden (voorzitter) com- } \\
\text { missie }\end{array}$ \\
\hline 74 lid I & $7: 13$ lid 6 & deels analoog & schriftelijk advies \\
\hline 74 lid 2 & - & - & geen nieuwe adviesaanvraag \\
\hline 75 lid I & 8:104 lid I & deels analoog & hoger beroep \\
\hline 75 lid 2 & 8:105 lid I & - & hoger beroepsinstantie \\
\hline 76 & $6: 7$ jo. $6: 24$ & deels analoog & termijn/indiening \\
\hline $76 a$ & $6: 15$ jo. $6: 24$ & analoog & doorzendplicht \\
\hline 77 & $6: 24$ & deels analoog & schakelbepaling hoger beroep \\
\hline 77 & $8: 108$ & - & toepasselijk procesrecht \\
\hline 77 lid I & 8:109 & - & griffierecht \\
\hline 77 lid I jo. 50 lid 9 & $8: 118$ & deels analoog & veroordeling in proceskosten \\
\hline 77 lid 2 & - & - & bevoegdheden voorzitter \\
\hline 78 lid I & 8: I I3 lid I & analoog & uitspraak \\
\hline 78 lid 2 & $8: 115$ & deels analoog & terugverwijzing \\
\hline $\begin{array}{l}78 \text { lid } 2 \text { laatste bij- } \\
\text { zin }\end{array}$ & $8: 116$ & analoog & zelf afdoen \\
\hline 78a lid I & - & - & intrekken/wijzigen besluit in primo \\
\hline $78 a$ lid 2 & 6:19 lid 3 jo. $6: 24$ & analoog & \\
\hline $78 b$ lid I & 6:19 lid I jo. 6:24 & analoog & $\begin{array}{l}\text { hoger beroep mede betrekking op } \\
\text { intrekking of wijziging besluit in } \\
\text { primo }\end{array}$ \\
\hline $78 b$ lid 2 & $6: 19$ lid 2 jo. $6: 24$ & analoog & ook na ingesteld hoger beroep \\
\hline $78 b$ lid 3 & 6:19 lid 4 jo. $6: 24$ & analoog & doorzendplicht \\
\hline $78 b$ lid 4 & 6:19 lid 5 jo. $6: 24$ & analoog & verwijzen naar Gerecht \\
\hline $78 b$ lid 5 & $6: 19$ lid 6 & analoog & vernietiging na intrekking \\
\hline $78 c$ lid I & 6:19 lid I jo. 6:24 & analoog & $\begin{array}{l}\text { hoger beroep mede betrekking op } \\
\text { beschikking ter uitvoering uitspraak } \\
\text { Gerecht }\end{array}$ \\
\hline $78 c$ lid 2 & 6:19 lid 3 jo. $6: 24$ & analoog & mededeling aan Hof \\
\hline 78d lid I & $6: 20$ lid 3 jo. 6:24 & analoog & $\begin{array}{l}\text { hoger beroep mede betrekking op } \\
\text { alsnog besluit in primo }\end{array}$ \\
\hline 78d lid 2 & $6: 20$ lid 2 jo. $6: 24$ & analoog & mededeling aan Hof \\
\hline 78d lid 3 & $6: 20$ lid 4 jo. $6: 24$ & analoog & verwijzen naar Gerecht \\
\hline 78d lid 4 & $6: 20$ lid 4 jo. $6: 24$ & analoog & alsnog gegrond \\
\hline $78 e$ & 8: I I4 lid I & analoog & terugbetalen griffierecht \\
\hline 79 lid I & $8: 54$ & deels analoog & vereenvoudigde behandeling \\
\hline 79 lid 2 & $8: 54$ lid 2 & deels analoog & procesrecht/wijzen op verzet \\
\hline
\end{tabular}


(Vervolg)

\begin{tabular}{|c|c|c|c|}
\hline Lar Curaçao & Awb & $\begin{array}{l}\text { analogie (deels als } \\
\text { ongeschreven recht) }\end{array}$ & onderwerp \\
\hline 79 lid 3 & - & - & artikel 8-procedure \\
\hline 79 lid 4 & 8:54 jo. 8:108 & deels analoog & ook in hoger beroep \\
\hline 80 lid I & 8:55 lid I & deels analoog & verzet \\
\hline 80 lid 2 & 8:55 lid 4 & deels analoog & horen indiener \\
\hline 80 lid 3 & $8: 55$ lid 9 & analoog & verzet gegrond \\
\hline 80 lid 4 & $8: 55$ lid 7-10 & deels analoog & uitspraak \\
\hline 8 I lid I & 8:52 lid I & deels analoog & versnelde behandeling \\
\hline 81 lid 2 & - & - & $\begin{array}{l}\text { in behandeling nemen voordat grif- } \\
\text { fierecht is betaald }\end{array}$ \\
\hline 82 lid I & $8: 52$ lid 2 & deels analoog & $\begin{array}{l}\text { tijdstip behandeling/afschrift stuk- } \\
\text { ken naar bestuursorgaan }\end{array}$ \\
\hline 82 lid 2 & - & - & $\begin{array}{l}\text { stukken tot zeven dagen voor zit- } \\
\text { ting }\end{array}$ \\
\hline 82 lid 3 & $8: 53$ & deels analoog & alsnog gewone behandeling \\
\hline 83 & - & - & onmiddellijke afwijzing \\
\hline 84 lid I & - & - & artikel 8-procedure \\
\hline 84 lid 2 & 8:52 e.v. jo. 8: 108 & deels analoog & in hoger beroep \\
\hline 85 lid I & $8: 81$ & deels analoog & voorlopige voorziening \\
\hline 85 lid 2 & 8:8I lid I & analoog & bevoegde rechter \\
\hline $\begin{array}{l}85 \text { lid } 3 \text { eerste vol- } \\
\text { zin }\end{array}$ & $8: 81$ lid 4 & - & overeenkomstige regels \\
\hline $\begin{array}{l}85 \text { lid } 3 \text { tweede vol- } \\
\text { zin }\end{array}$ & $8: 82$ & deels analoog & griffierecht \\
\hline 86 & $8: 84$ & deels analoog & beslissing \\
\hline 87 lid I & 8:83 lid I & deels analoog & getuigen, deskundigen, tolken \\
\hline 87 lid 2 & 8:62 jo. $8: 83$ lid I & deels analoog & horen in openbaar \\
\hline 87 lid 3 & $8: 83$ lid 4 & analoog & beslissing zonder zitting \\
\hline 88 & - & - & schorsing \\
\hline 89 lid I & $\begin{array}{l}8: 72 \text { lid } 6 \text { jo. } 8: 84 \\
\text { lid } 5\end{array}$ & analoog & dwangsom \\
\hline 89 lid 2 & 8:87 lid I & deels analoog & wijzigen vovo \\
\hline 90 & $8: 87$ & deels analoog & opheffing/wijziging \\
\hline 91 & $8: 85$ & deels analoog & vervallen vovo \\
\hline 92 lid I & $8: 80$ jo. $8: 84$ lid 5 & analoog & bekendmaking schorsing \\
\hline 92 lid 2 & $8: 80$ jo. $8: 84$ lid 5 & analoog & bekendmaking vovo \\
\hline 93 & $8: 84$ lid 4 & analoog & toezending beslissing \\
\hline 94 lid I & - & - & vovo in artikel 8-procedure \\
\hline 94 lid 2 & $\begin{array}{l}\text { 8:8I e.v. jo. 8: } 108 \\
\text { lid I }\end{array}$ & analoog & \\
\hline
\end{tabular}




\begin{tabular}{|c|c|c|c|}
\hline Lar Curaçao & Awb & $\begin{array}{l}\text { analogie (deels als } \\
\text { ongeschreven recht) }\end{array}$ & onderwerp \\
\hline 95 lid I & $8: 86$ lid I & deels analoog & kortsluiting \\
\hline $95 \operatorname{lid} 2$ & - & - & $\begin{array}{l}\text { regels van overeenkomstige toepas } \\
\text { sing }\end{array}$ \\
\hline $95 \operatorname{lid} 3$ & - & - & artikel 8-procedure \\
\hline $95 \operatorname{lid} 4$ & 8:86 jo. 8:108 lid I & deels analoog & kortsluiting in hoger beroep \\
\hline 95 lid 5 & $8: 86$ lid 3 & analoog & voorlichting over kortsluiting \\
\hline 96 lid I & 8:119 lid I & analoog & herziening \\
\hline 96 lid 2 & $8: 119$ lid 2 & deels analoog & procesregels herziening \\
\hline 97 lid I & - & - & $\begin{array}{l}\text { mededeling bestuursorgaan bij niet } \\
\text { gevolg geven aan uitspraak }\end{array}$ \\
\hline $97 \operatorname{lid} 2$ & - & - & verzoek om voorziening \\
\hline 98 lid I & - & - & verzoek om vergoeding/nakoming \\
\hline 98 lid 2 & - & - & termijn zes weken \\
\hline $98 \operatorname{lid} 3$ & - & - & uitspraak/dwangsom \\
\hline 98 lid 4 & - & - & $\begin{array}{l}\text { regels van overeenkomstige toepas. } \\
\text { sing }\end{array}$ \\
\hline 99 & - & - & $\begin{array}{l}\text { van overeenkomstige toepassing in } \\
\text { hoger beroep }\end{array}$ \\
\hline 100 & $2: 5$ & deels analoog & geheimhoudingsplicht \\
\hline 101 & - & - & strafbepaling \\
\hline 103 & $11: 4$ & - & citeertitel \\
\hline
\end{tabular}

